\title{
Unseen sentinels: local monitoring and control in conservation's blind spots
}

\author{
Douglas Sheil $^{1,2}$, Manuel Boissière $^{2,3}{\text { and } \text { Guillaume Beaudoin }^{2}}^{2}$
}

\begin{abstract}
Although official on-the-ground environmental monitoring is absent over much of the world, many people living in these regions observe, manage, and protect their environment. The autonomous monitoring processes associated with these activities are seldom documented and appear poorly recognized by conservation professionals. We identified monitoring activities in three villages in the Mamberamo-Foja region (Mamberamo Regency) of Papua (Indonesian New Guinea). In each village we found evidence that local monitoring contributes to effective protection and deters unregulated exploitation. Although everyone gathers observations and shares information, there are also specific roles. For example, the Ijabait hereditary guardians live at strategic sites where they control access to resource-rich lakes and tributaries along the Tariku River. Often, monitoring is combined with and thus influences other activities: for example, hunting regularly includes areas judged vulnerable to incursions by neighboring communities. We identified various examples of community members intervening to prevent and deter outsiders from exploiting resources within their territories. Enforcement of rules and assessment of resource status also help prevent local overexploitation within the communities. Clearly, local people are effective in protecting large areas in a relatively natural state. We discuss the value of these autonomous monitoring and protection processes, their neglect, and the need for explicit recognition by those concerned about these people and their environments, as well as about conservation. We highlight a potential "tragedy of the unseen sentinels" when effective local protection is undermined not because these local systems are invisible, but because no one recognizes what they see.
\end{abstract}

Key Words: autonomous monitoring; common property; community conservation; community management; deterrence; Indonesia; managing the commons; Papua; participatory resource assessment; policing

\section{INTRODUCTION}

Official protection of the world's biodiversity is underfunded and inadequate (McCarthy et al. 2012, McCreless et al. 2013). Although $12 \%$ of the world's surface is officially protected (Chape et al. 2005), much of this area lacks effective management (Bruner et al. 2001, Brooks et al. 2009). Even well-funded conservation areas are unable to prevent erosion of their values or to nullify every threat (e.g., Solomon et al. 2007, Scholte and De Groot 2010, Baker et al. 2012). Furthermore, numerous species, including many of conservation interest, either occur primarily outside formal protected areas or require larger areas to ensure viability (Rodrigues et al. 2004, Ricketts et al. 2005, Brooks et al. 2009). Even when good environmental regulations exist outside protected areas, enforcement is often inadequate to prevent unsustainable exploitation and habitat degradation (ContrerasHermosilla 2002; Galinato and Galinato 2013). There are also concerns about the sustainability of conservation measures imposed on people without their consent or any proper democratic accountability (Sheil et al. 2013). Although many conservationists continue to press for the expansion of formal protected areas, less attention has been paid to some alternatives.

Most regions of the world are inhabited. These inhabitants often engage in practices that protect the environment from conversion, degradation, and overexploitation, and contribute to conservation outcomes (Berkes et al. 2000, Colding and Folke 2001, Vermeulen and Sheil 2007a). Communities control an estimated total area of relatively wild habitat similar in extent to that within official protected areas; modified landscapes sustain additional conservation values (Molnar et al. 2004). So, although the ability of formal conservation agencies to control, expand, and improve environmental protection is limited, local people may to some extent be filling the gap.
Monitoring, i.e., a sustained or intermittent process of assessing change or threats, is fundamental to environmental stewardship (Sheil 2001). Effective management means threats and problems are recognized, evaluated, and addressed, and ideally anyone who might cause problems is deterred from doing so. We recognize this monitoring process when official managers gather and respond to observations and data, but are less explicitly aware of comparable activities by local people and what they achieve. However, everyone assesses their environment and what is occurring in it, and reacts as they judge most appropriate. Thus, monitoring occurs wherever people are living in, and depending on, their natural environment.

Autonomous local monitoring, i.e., monitoring that is determined and maintained without the need for external guidance or support, has seldom been examined in any detail. Many researchers, including ourselves, have noted the environmental trends recognized by local people without necessarily considering the function, scope, and operational details of how this recognition is achieved (e.g., Hellier et al. 1999, Lund et al. 2010, Basuki et al. 2011, Boissière et al. 2013, Padmanaba et al. 2013, Danielsen et al. 2014a, 2014b). Active oversight is implicit in work on traditional resource management (Berkes et al. 1998) and in the context of collaborative or participatory monitoring (Danielsen et al. 2009). The principle of self-policing is highlighted in the literature on common property management (Ostrom 1990, Rustagi et al. 2010), but again the associated monitoring processes are generally implicit. Furthermore, such policing and processes have seldom been examined in other property systems (see Appendix 1 for further elaboration).

We hypothesize that all societies that maintain significant day-today control over their territories and resources also monitor them:

${ }^{1}$ Department of Ecology and Natural Resource Management, Norwegian University of Life Sciences, ${ }^{2}$ Center for International Forestry Research, ${ }^{3}$ Centre de coopération Internationale en Recherche Agronomique pour le Développement 
i.e., such practices are a general aspect of how people live when external controls are weak or absent. This hypothesis implies that such monitoring processes would once have been near-universal and may remain commonplace. Beyond this, we want to understand if these systems remain effective in contributing to environmental conservation and protection.

Our goal is to highlight the existence and significance of local monitoring practices, drawing on our own observations in three communities, Kay, Metaweja, and Yoke, in the Mamberamo-Foja region, most of which lies within the recently created regency of Mamberamo Raya of Papua (Indonesian New Guinea, previously Irian Jaya). This vast region has received little systematic attention from biological researchers (Marshall and Beehler 2007, Takeuchi 2009, Normile 2010, van Heist et al. 2010, Keim 2012, Oliver et al. 2012), but biodiversity values appear high and local conservation authorities have little oversight (Marshall and Beehler 2007). In 2009, a total of 143 conservation staff were responsible for 4,621,596 hectares of officially protected areas across the entire Province of Papua (with much more in the process of gaining protected status), as well as various other conservations tasks (Departmen Kehutanan 2010).

We consider local monitoring with an emphasis on natural resource management, environmental protection, and conservation. We describe local monitoring and seek examples of enforcement, deterrence, and restraint that contribute to maintaining conservation values. We focus on outcomes: we accept that people may not hold conventional "conservation motives" (for a wider discussion, see Smith and Wishnie 2000, Wadley and Colfer 2004, Vermeulen and Sheil 2007a). Our study region and study topic have received little attention from researchers in the past; thus, we provide more context in two appendices. More detailed information on the three communities, based on our own observations, interviews, and enquiries, is in Appendix 2. We provide a brief literature-based discussion of autonomous monitoring in Appendix 1.

\section{METHODS}

\section{Sites}

We worked in three communities: Kay, Metaweja, and Yoke, in the Mamberamo-Foja watershed (Fig. 1). The Mamberamo-Foja watershed possesses many rare, vulnerable, little-known, and undescribed species, and is considered to have globally significant biodiversity values (Richards and Suryadi 2002, Boissière et al. 2006, 2007, Marshall and Beehler 2007, van Heist et al. 2010). Most of the area is covered by forested mountains and flood plains, and also contains open wetlands with meandering rivers and shifting lakes (Fig. 2a, b, c). People are concentrated in settlements of varying size, allowing river access (Fig. 2d), with low overall population densities. Official sources report 19,839 people in the $23,813 \mathrm{~km}^{2}$ of Mamberamo Raya (RTRW 2009). Local livelihoods remain highly dependent on wild resources (see Fig. 3a-g).

Difficult access, malaria, and communities willing to confront intruders have discouraged settlement and exploitation by outsiders (Richards and Suryadi 2002, Sheil and and Boissière 2006, van Heist et al. 2010). External threats include mining, logging, plantation developments, and a proposed hydroelectric dam (Richards and Suryadi 2002, Marshall and Beehler 2007).
At the time of our survey, Kay was divided into two settlements on the Tariku River, and people from upstream visited the village on their way to the settlements of Dabra or Kasonaweja. Metaweja was more difficult to access because of the steeply incised terrain. Yoke was on the coast, near the Mamberamo estuary and easily accessible from Kasonaweja, Sarmi, and elsewhere.

Fig. 1. Map indicating the location of our study, Kay (1 and 2), Metaweja, and Yoke and their relation to Kasonaweja, and the Mamberamo-Foja Wildlife Reserve (inset map shows relation to Papua). Note the two main tributaries to the Mamberamo were known as the Rouffaer and Idenburg under Dutch rule but are now named the Tariku and the Taritatu.



Fig. 2. Typical land cover and features in the Mamberamo region. (a) Foothills of the Foja Mountains (DS); (b) dynamic flood plains with shifting rivers (MB); (c) mixed forest with sago palms (DS); (d) typical riverside huts near Kay (MB).

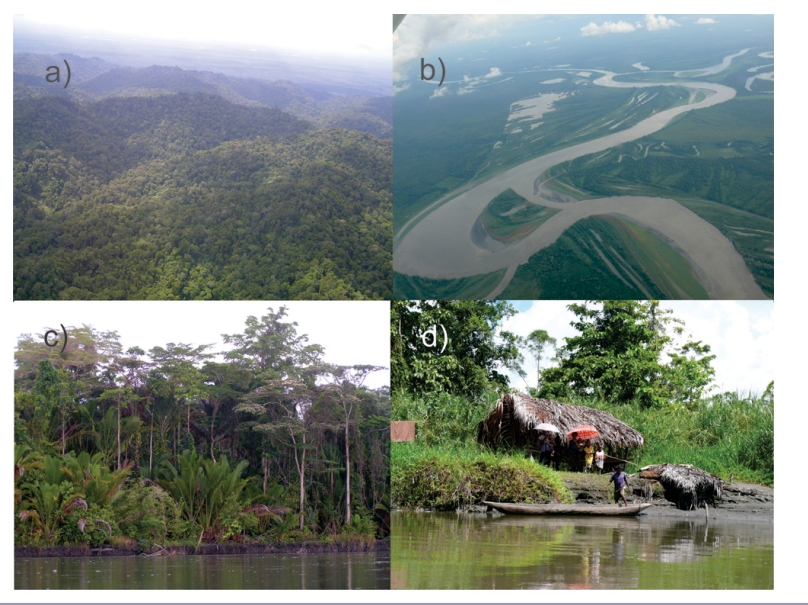


Table 1. The three communities considered in the Mamberamo Watershed (Papua, Indonesia): their populations, territories, ethnicity and languages, livelihood, livelihood concerns (as stated in focus group discussions), how land and resources are determined, authority, and relationship with government authorities.

\begin{tabular}{|c|c|c|c|c|c|c|c|c|}
\hline $\begin{array}{l}\text { Community } \\
\text { Pop. / } \\
\text { area } \mathrm{km}^{2}\end{array}$ & Ethnicity & Language & Primary livelihood activities & $\begin{array}{l}\text { Livelihood } \\
\text { concerns } \\
\text { regarding } \\
\text { resource and } \\
\text { area control }\end{array}$ & Sacred sites & $\begin{array}{l}\text { Land/ resource } \\
\text { ownership/ control }\end{array}$ & $\begin{array}{l}\text { Principal } \\
\text { authorities }\end{array}$ & $\begin{array}{l}\text { Relationship with } \\
\text { higher authorities }\end{array}$ \\
\hline \multicolumn{9}{|l|}{ Kay } \\
\hline $\begin{array}{l}163 / \\
1300\end{array}$ & $\begin{array}{l}\text { Kwersa, } \\
\text { Torweja, } \\
\text { Wekerig }\end{array}$ & $\begin{array}{l}\text { Kwersa \& } \\
\text { Torweja }\end{array}$ & $\begin{array}{l}\text { Gathering wild sago, } \\
\text { cultivating mixed gardens, } \\
\text { fishing, hunting crocodiles, } \\
\text { pigs, cassowaries, NTFP } \\
\text { collection (e.g., matoa, } \\
\text { gnetum, wild guava) }\end{array}$ & $\begin{array}{l}\text { Extensive } \\
\text { territory to } \\
\text { protect from } \\
\text { outsiders }\end{array}$ & $\begin{array}{l}\text { Yes, located } \\
\text { upstream }\end{array}$ & By clan & $\begin{array}{l}\text { Head of village } \\
\text { (gov.), clan } \\
\text { leaders, pastor }\end{array}$ & Very limited \\
\hline \multicolumn{9}{|l|}{ Metaweja } \\
\hline $\begin{array}{l}225 / \\
300\end{array}$ & Kawera & Kawera & $\begin{array}{l}\text { Hunting (pigs, cassowaries, } \\
\text { birds), NTFP collection (e. } \\
\text { g., gnetum, matoa, } \\
\text { breadfruit, mushrooms), } \\
\text { sago cultivation, wild sago, } \\
\text { few mixed crop gardens, } \\
\text { coconut groves }\end{array}$ & $\begin{array}{l}\text { Isolation with } \\
\text { poor access to } \\
\text { markets; } \\
\text { developing } \\
\text { infrastructures }\end{array}$ & $\begin{array}{l}\text { Yes, on hill } \\
\text { tops near } \\
\text { the village }\end{array}$ & By clan & $\begin{array}{l}\text { Head of village } \\
\text { (gov.), pastor } \\
\text { (same person), } \\
\text { clan leaders (the } \\
\text { main customary } \\
\text { leader resides } \\
\text { elsewhere } \\
\text { (Kasonaweja) }\end{array}$ & Very limited \\
\hline \multicolumn{9}{|l|}{ Yoke } \\
\hline $\begin{array}{l}339 / \\
1400\end{array}$ & $\begin{array}{l}\text { Paito \& } \\
\text { Bosumbaso }\end{array}$ & Yoke & $\begin{array}{l}\text { Fishing, sago cultivation, } \\
\text { collecting wild sago, minor } \\
\text { gardening, minor hunting } \\
\text { of crocodiles, lizards, } \\
\text { cassowaries, NTFP } \\
\text { collection (e.g., clam, crabs, } \\
\text { gnetum, ferns) }\end{array}$ & $\begin{array}{l}\text { Outsiders fishing } \\
\text { without consent }\end{array}$ & $\begin{array}{l}\text { Yes, where } \\
\text { some } \\
\text { channels } \\
\text { intertsect in } \\
\text { the tidal } \\
\text { swamp }\end{array}$ & $\begin{array}{l}\text { Shared (clan } \\
\text { divisions avoided } \\
\text { in near-village } \\
\text { contexts); for sago } \\
\text { groves and garden } \\
\text { areas clan } \\
\text { ownership prevails }\end{array}$ & $\begin{array}{l}\text { Head of village } \\
\text { (gov.); customary } \\
\text { leader, pastor }\end{array}$ & $\begin{array}{l}\text { Some } \\
\text { relationship with } \\
\text { local government } \\
\text { (vice head of } \\
\text { Regency- } \\
\text { Kabupaten is } \\
\text { from Yoke) }\end{array}$ \\
\hline
\end{tabular}

The total area of the three community territories was 3000 square kilometers (see Table 1). Each territory was further subdivided by clans. All three territories overlapped the 2,000,000-hectare Mamberamo-Foja Wildlife Reserve (an official status that prohibits human settlement or exploitation, although this has not been enforced). This reserve was declared in 1982 without local consultation and is officially "controlled" by the Balai Besar Konservasi Sumber Daya Alam (BBKSDA; Natural Resource Conservation Agency). The reserve was unstaffed and seldom visited by BBKSDA staff. We are aware of only three visits and two were because of the participation of BBKSDA in our study; the other was a check on crocodile hunters (BBKSDA staff, personal communication; authors, personal observation). Despite the overlap with their territories, communities were unaware of the protected area until 2005 and have maintained their own claims, customs, and rules governing these areas. Within these territories only particular people have rights to engage in, or to permit, certain activities in specific areas; in sacred areas any human presence is discouraged by taboos and/or prohibitions.

Selected community characteristics are summarized in Table 1, including population, territory size, ethnicity and languages, livelihood activities, livelihood concerns, sacred sites, ownership and controls over land and resources, community authorities, and relationship with government authorities at the time of our study (2006 to 2013). Additional information is in Appendix 2.

\section{Approach and methods}

We built trust through our activities over several years. Activities included (1) mapping local and customary needs, perceptions, and practices; (2) an examination of community resilience to climatic variation and change; (3) an examination of the context for participation in Measuring, Reporting and Verifying carbon stocks and related activities; and (4) this study. We selected our three communities based on the opportunity provided by our field work plans and to represent a range of distinct locations and lifestyles (coastal, riverside, far upstream). More detail on these activities and methods can be found in various reports and publications, such as Boissière et al. (2007). Boissière et al. (2006; in Indonesian) provide details of our initial work concerning local perceptions and preferences about landscapes and natural resources, based on methods described in Sheil et al. (2002). Padmanaba et al. (2012) describe the process of participatory land planning. Boissière et al. (2013) describe our assessment of community views regarding climate variability.

Our team members included male and female interviewers. We also included staff from local government agencies (the Forestry Department and Badan Perencana Pembangunan Daerah, the regional body for planning and development). In each community we started with meetings where we presented our reasons for being there, what we hoped to achieve, how we hoped we could work together, and what we could and could not offer. We answered questions, sought permission for the activities, and asked for 
Table 2. Local monitoring observed in the Mamberamo Watershed (Papua, Indonesia) by community, including goals, activities, and how monitoring is undertaken. In each village we identified distinct processes (numbers) that themselves may address more than one issue or be used in more than one way (numbers subdivided by letter).

\begin{tabular}{|c|c|c|c|c|c|}
\hline $\begin{array}{l}\text { Community and } \\
\text { area's official } \\
\text { status }\end{array}$ & Goals & Activities & $\begin{array}{l}\text { Who is involved? Organization, } \\
\text { leadership, institutions }\end{array}$ & $\begin{array}{l}\text { Data and how it } \\
\text { leads to decisions }\end{array}$ & Frequency and response \\
\hline $\begin{array}{l}\text { Kay } \\
\text { Part of the } \\
\text { territory within } \\
\text { protected area } \\
\text { and part in }\end{array}$ & $\begin{array}{l}1 \text { Control access } \\
\text { to lakes (fish, } \\
\text { crocodiles, and } \\
\text { other resources). }\end{array}$ & $\begin{array}{l}1 \text { Families settle at locations with } \\
\text { good visibility (also convenient for } \\
\text { their own resources access). }\end{array}$ & $\begin{array}{l}1 \text { Hereditary/voluntary but } \\
\text { approved and overseen by male } \\
\text { clan elders. }\end{array}$ & $\begin{array}{l}1 \text { Observations of who is doing } \\
\text { what and where. Also attention to } \\
\text { status of local resources. }\end{array}$ & $\begin{array}{l}1 \text { Observations are near continuous. } \\
\text { This is an effective deterrent. Any } \\
\text { major breach of the territory could } \\
\text { escalate to fines and/or } \\
\text { confrontation. }\end{array}$ \\
\hline
\end{tabular}

forest.

\begin{abstract}
2 Control 2a Families stay for several days on movements along small alluvial river islands with the main river and good visibility onto the river. They access to make gardens and fish.

resources $\begin{array}{ll}\text { (crocodiles, fishes, } & \text { 2b All villagers will report or } \\ \text { sago). } & \text { challenge any unauthorized visitor }\end{array}$ they see.

3 Determine 3 a Fish resources are assessed resources to avoid Yoke but appears more casual and overharvest.
\end{abstract}

2a Voluntary but approved and overseen by male clan elders. Tends or fish near these islands. These gardens generally belong to families (not clan level)

$2 \mathrm{~b}$ Report to clan elders and to village head.

3 Fishers and hunters assess wher the resource is most readily available and avoid areas where more effort will be required. to be determined by wish to hunt

2 Observations of who is doing what and where are directly shared in the village and decisions are made by clan leaders.

3 Assessments are based on local experience and judgement. Information is shared and discussed to build general awareness, which helps track and judge options (where to access, what and where to avoid). Restraints and controls will be discussed by clan leaders and local owners if depletion becomes a concern.

(i) During the dry season, by tracks (associated with nesting [egg laying] on the river banks).

(ii) Hunters use torches at night to spot crocodiles. This is efficient as eyes are reflective and the stronger the reflection the larger the crocodile.

$\begin{array}{ll}\text { Metaweja } & 1 \text { Control acces } \\ \text { Territory lies } & \text { to territory and }\end{array}$ within protected resources. area.

2a Resource protection.

2b Resource status.
1 Huts and semipermanent camps owned by particular families are strategically located at borders with neighboring villages. They include gardens and sago stands around the camp (stays may be 1 day to 1 month, stated goals include hunting, sago cultivation or harvest, camp maintenance).
1 Individuals or groups (mostly young men, but sometimes women and families) volunteer from local clan. Specific people have knowledge of specific locations and assume local responsibility.

Information is widely shared and discussed within the village. Problems or events would be reported and discussed with clan leaders and village head.

2 During hunting, food gathering, 2 Everyone is active within the and other activities villagers gather larger territory either in groups or direct observations and signs of (a) alone.

people's activities and intrusions

(b) valued species and resources. heard, or indirectly detected (foot prints, camps, etc.).
Yoke within protected resources (fishes, area. 1a Village strategically located. All villagers may see and challeng visitors. This is a deterrent

1b One family lives on Lake Tabaresia (a mangrove system). They observe and help control who uses this lake.
1 Resources must be gained through the villagers: generally a price will be agreed and the villagers collect the resource for the outsiders.

Villagers take direct action or report to the clan leaders and the village secretary (government representative present in the village) when an outsider is entering.
1 Those active in area are seen,

Anyone will immediately challenge intruders directly, ask their intent (they may confiscate their catch).

Rarely they might expel an intrude or confiscate a boat.

Visitors and outsiders can ask permission for activities from clan leaders.

2a Signs of people's activities may be carefully scrutinized and intruders may be intercepted.

Actions will be taken according to $2 \mathrm{~b}$ Resource availability and status is the scale of problems identified. In discussed on a near daily basis and principle the entire community may areas are accessed or avoided act together.

2b Abundance assessments from hunting effort and yield. General status of animals and plants are gathered through familiarity of signs, of success while hunting an gathering. All these factors are discussed by the hunters.

1 Information of outsiders and their movements and activities. Intercept and take action against incursions.

Observations shared in the village and decisions made by leaders and head of village. een invoked though informants noted that fish poison had been banned because of a decline in fish, but we heard that people still use it and it is a cause of conflict. There is a similar discussion about fine meshed nylon nets.

1 Observations are near continuous. Coordinated actions based on information received: perpetrators may be required to pay fine.

1a Neighboring villages visit every week and outsiders ask permission perhaps once a year. Larger boats have been challenged several times in recent decades. 
2 Assess resource status.
Resources are assessed based on catches (abundance, size, quality) and effort required by location.
2 All villagers involved (women are 2 General awareness guides

specialized in crab collection). Assessments are based on experience and judgement. Information is shared and discussed to build general awareness of resource status. extraction options (what to access and where). The need for restraints and controls can be discussed by village leaders and local owners. Typically, however, they just focus on gathering what they need where it is most readily available.

\author{
2 Daily assessments and \\ discussions. When resources \\ are seen to be declining \\ controls or prohibition on \\ extraction could be agreed \\ and imposed by local owners \\ and other leaders. But such \\ processes have not been \\ needed in many years. \\ Apparently resources are \\ more than adequate for the \\ community.
}

informants to help inform our research. The information used in this study was derived from field visits, interviews, discussions, and participatory exercises (Fig. 4a-d). Initial work helped generate engagement and build trust (Boissière et al. 2006, 2007). Additional visits to the region occurred over five years in conjunction with other projects, allowing some communities to be visited multiple times. We also met villagers from the different communities when we visited Kasonaweja, which we did regularly. That provided an update on what was going on in relationships with outsiders and other villages, and in implementing land use planning. These meetings were also a chance to check details.

Fig. 3. Selected livelihood activities based on natural resources. (a) Hunter carries a pig back to the village (Metaweja, GB); (b) fishermen catch various aquatic creatures, here a freshwater soft-shelled turtle, likely Pelochelys signifera (hunter's face obscured by authors to protect identity, MB); (c) fishing with harpoons (Yoke, MB); (d) young crocodile, Crocodylus novaeguineae or Crocodylus porosus, caught in fishing nets (Kay, MB); (e) fish are cooked and dried/smoked (Kay, DS); (f) the main starch in people's diets is derived from the processing of wild and planted sago (Metaweja, MB); (g) large timber trees are locally plentiful on drier land and are processed for constructing local buildings (Kay, DS).

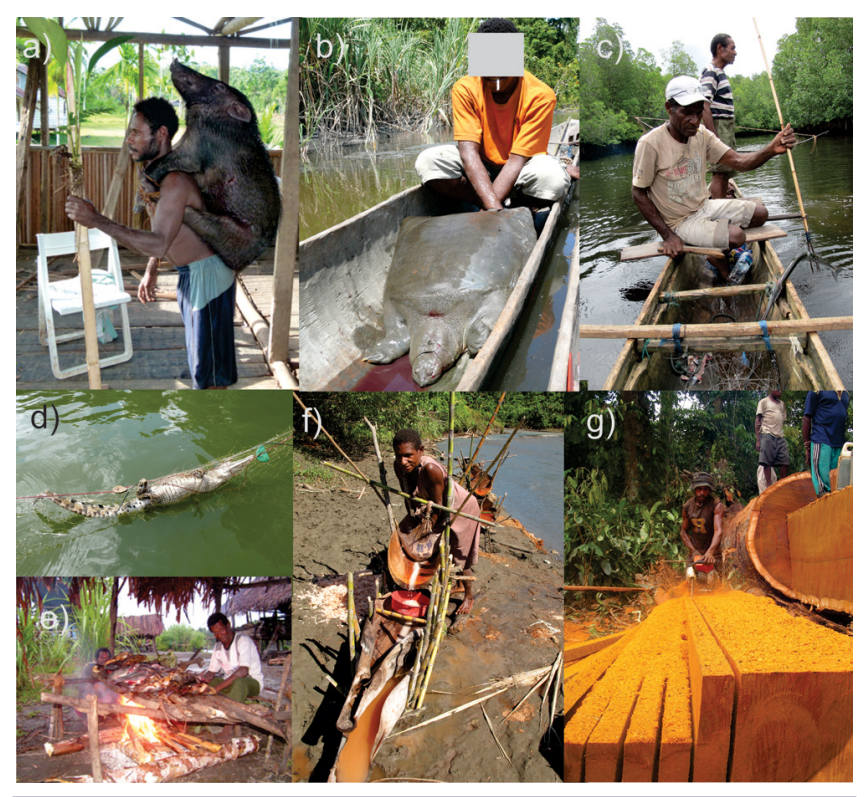

Activities included participatory mapping with four selected groups (young men, old men, young women, and old women) and joint exercises to identify and clarify the local importance and significance of categories and types of land cover and location, and the importance and significance of different species (Sheil et al. 2002, Sheil and Liswanti 2006). In each exercise we involved groups of male and female informants. Our field teams included female interviewers who engaged the women. After the maps had been drafted and checked by community members and field visits, they were finalized, printed on plasticized paper, and returned to each community.

Fig. 4. Methods used to engage community members regarding the examples in this study. (a) Field visits with informants (Kay, DS); (b) focus group discussion around the results of the initial participatory mapping with a group of women (Metaweja, GB); (c) discussing locations on participatory map with men (Yoke, $\mathrm{MB})$; (d) hunters scoring the frequency of visits to the community boundary (Metaweja, GB).

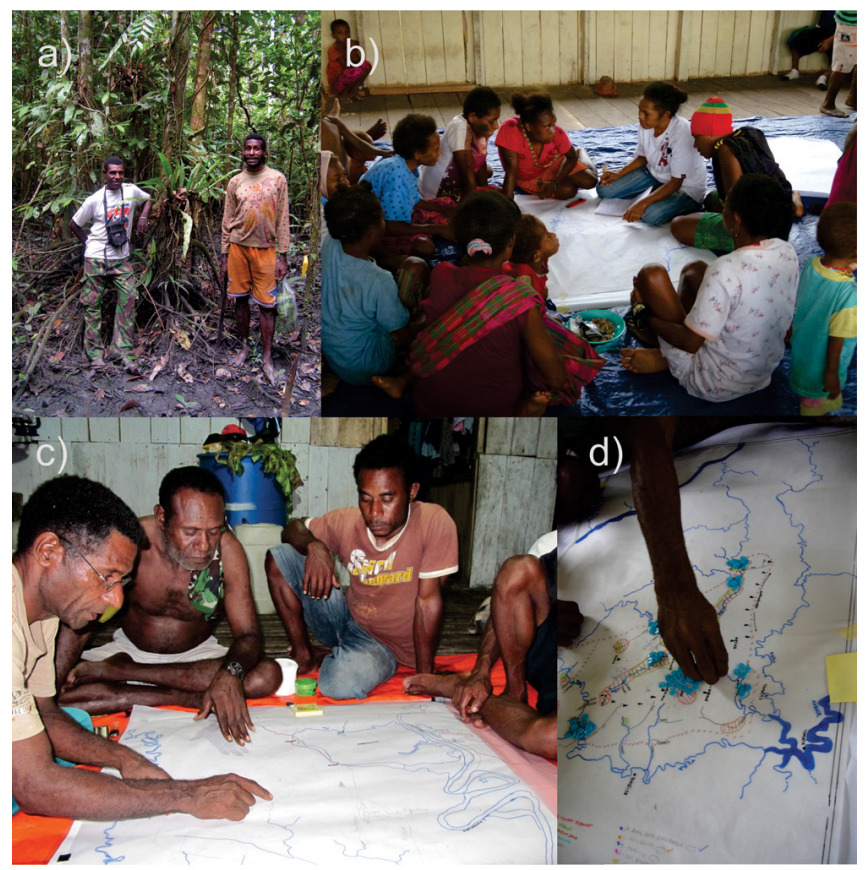


In Yoke and Metaweja we used dedicated group discussion (same number and arrangement as participatory mapping) on local monitoring of resources, territory, and borders. In the three communities, we surveyed and interviewed 83 heads of households as part of household surveys and conducted an additional formal 60 interviews covering topics such as village institutions; rules, norms, and traditional rules; local land use and natural resources management; sacred places; relationships with external authorities; history; land use; and trade, products, and resources. Many field visits were undertaken, and there were many less formal discussions during the course of the studies that also identified or clarified relevant issues and examples. We visited field camps, gardens, sacred sites, and the area controlled by one Ijabait close to Kay. In Yoke we visited the base of the lake guardian. We also conducted specific group exercises to identify, discuss, and characterize monitoring activities in Yoke and Metaweja.

Most of the initial identification of monitoring and guarding activities arose from the participatory mapping and focus group discussions on the importance of forest and forest products, and on the rules about access and use. Much of the further clarification derived from informal discussions with individuals and small groups during visits to specific locations as part of our program of field checking the various participatory maps in all three communities. These field checks, when done by boat, generally involved researchers traveling with at least three local people, two to manage the boat and one elder with local expertise and authority. When done on land, the researchers generally worked with at least two or more local people who knew the area, although these numbers were sometimes much larger. For example, in Metaweja entire families joined some trips because it was an opportunity to visit remote hunting areas and gardens (and keep an eye on the researchers). The group exercises were required to map and explore the typical frequency of monitoring activities.

Informants were repeatedly reminded that the research results would be shared with an outside audience and were invited to voice any concerns. If concerns remained after further discussion, we subsequently respected them. Thus, we do not talk about specific locations of high-value products. We worked in Indonesian using local translators when necessary. Most information was derived from multiple sources and crosschecked; for confidentiality and brevity, we shall not cite these sources for every statement. We identified and clarified various examples within each community that involve monitoring and control over resources. In each community we sought to find and elaborate specific examples showing effective responses to external and internal threats.

Those seeking to replicate our study would not need to conduct all the activities we did because we had multiple goals. However, they would need to invest the time required to build trust. We spent a lot of time, especially in the first few days in each community, explaining what we were doing and answering questions. Effort is also needed to develop effective communication. For example, the jointly made maps provided a shared basis for talking about places and associated activities, and we also spent a lot of time talking about types of places, roles, norms, rules, and resources, so as to develop an understanding of the basic labels used and what they imply. Observing what people are doing also has value-how they spend their time and understanding the rules about visiting different sites and accessing different resources by actually seeing the locations, resources, and practices in question. A lot of repetition and cross-checking were necessary. Rapid surveys would likely fail because they would lack trust and the time needed to build a credible understanding among the local people.

We also conducted a literature search for examples of people monitoring and policing the environment by and for themselves. Specifically we sought examples of monitoring in the tropics where design, implementation, and use of the monitoring are achieved autonomously by local people as part of a longestablished process of land and/or resource management. This is close to the category of "autonomous local monitoring" described in Danielsen et al.'s (2009) typology of participatory monitoring (see also Danielsen et al. 2014b). We used the terms "indigenous monitoring," "traditional monitoring," "community monitoring," "autonomous monitoring," "indigenous guarding," and "traditional guarding" in the ISI Web of Science database (http://thomsonreuters.com/thomson-reuters-web-of-science/.) The results and additional literature are discussed in Appendix 1.

\section{RESULTS}

In each village we found both threat monitoring and resource monitoring (summaries in Table 2 and Fig. 5a-f). Here, we expand on selected examples from each of the three communities.

\section{Kay}

At nine locations within the territory overseen by Kay, an Ijabait resides (see Fig. 5c as an example). An Ijabait is a patrilineal hereditary guardian whose primary role is to control local access for the clan that owns the territory. All nine locations provide strategic oversight of river access to resource-rich areas. Two sites are ox-bow lakes (Fig. 5e) and seven are tributaries to the main river, with abundant crocodiles, sago, and fish, and good dry season hunting for pigs and cassowaries. Some Ijabait control multiple locations in one vicinity and move among them. We were told that Ijabait seldom leave their area of responsibility, and hunt and fish locally to provide for their wife and children who live with them; other family members bring anything required from elsewhere.

The Ijabaits are respected and act as a powerful deterrent: we heard of no incidents of anyone trying to slip by unnoticed. Those we visited owned hunting dogs, which further increased the chance of detecting and catching intruders. Anyone entering the restricted territory would be intercepted. We were told that anyone caught with products would be punished (likely fined), although our informants remembered no specific incursions, either by outsiders or community members, despite the rich resources available. Our informants commented that such guarding activities were not restricted to Kay but were present in communities all along the Tariku River, where most channels and lakes were guarded.

Local lakes were, in general, connected to the main river only by narrow channels that may, we were told, occasionally be barricaded purposely with tree trunks to impede access. We never saw such blocks, but this practice would be used where the Ijabait was not located near the specific access point. Generally any such bans would be known and respected within the community: they would in principle also be enforced, although no one could recall any examples of this being necessary. 
Fig. 5. Contexts and activities associated with autonomous monitoring. (a) Settlements are strategically located and look out over the most valued fishing grounds (Yoke, MB); (b) regular camping sites include huts and gardens, here on the village territory boundary (Metaweja, MB); (c) the home of an Ijabait hereditary guardian by the Tariku (Rouffaer) River (Kay, DS); (d) anyone accessing these flood plain territories leaves visible tracks in the soft substrate (a tributary of the Tariku near Kay, DS); (e) accessing the resource-rich lakes is easiest via specific channels that can be closely monitored (Kay, DS); (f) monitoring of crocodiles is easiest using strong torch light at night. This is a method that people have adopted from a Food and Agriculture Organization of the United Nations team that assessed crocodile populations in the 1980s (Kay, $\mathrm{MB})$.

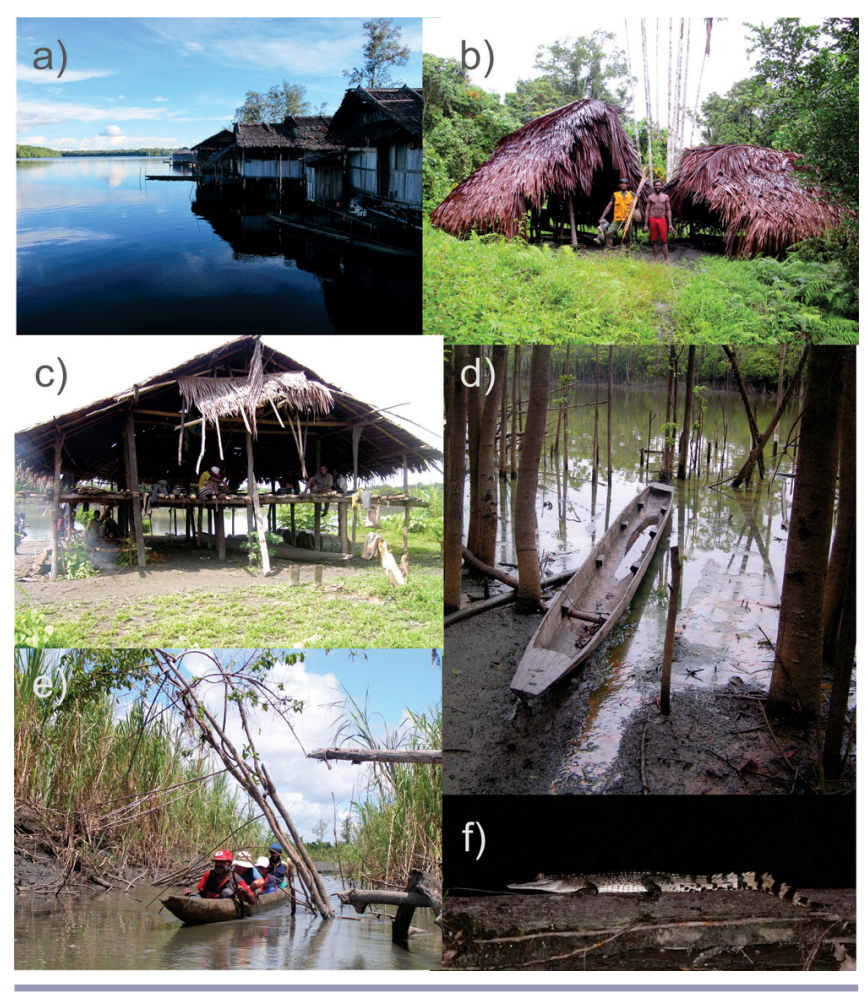

Status assessments were seen as a key determinant of the choice to harvest or protect resources. An interesting example is hunting crocodiles (Crocodylus novaeguineae and Crocodylus porosus); these were among the most important resources at Kay until recently and hunted primarily for their valued skin, with the flesh used as food. Only people from Kay had any right to hunt crocodiles; outsiders were never permitted. In the past animal stocks had been assessed from experience and accumulated observations, but in recent years animal numbers and sizes were assessed at night using hand-held spotlights (Fig. 5f). Harvesting was then stopped or reduced in any area where crocodile numbers appeared low. This judgment was made directly by those involved in the survey; there were no additional analyses.

The spotlight method originated from a Food and Agriculture Organization of the United Nations (FAO) team that conducted crocodile surveys in the 1980s (Frazier 1988). In each territory the FAO team explained the activity, asked permission, and was then accompanied by local clan representatives as they assessed the crocodiles. Interestingly this FAO project had also suggested that crocodile harvesting for both species be regulated by size (animals of $28-56 \mathrm{~cm}$ being "commercial belly width") to maintain a good breeding population (Frazier 1988, Cox 1992). Although initially viewed as interference, these regulations were subsequently adopted as part of Kay's code of rules and norms. Other communities in the region, such as Kwerba and Papasena, also adopted and adapted these methods and guidelines for managing crocodile harvesting (DS and MB, personal observation).

\section{Metaweja}

Territorial protection was a shared responsibility in Metaweja. Some households maintained huts or camped regularly at strategic locations near their territory boundaries. Attention was focused on boundaries with mistrusted communities. Metaweja's men reported the frequency of their visits to different portions of their territorial boundary (Fig. 4d). In total, around $50 \mathrm{~km}$ of the approximately $80-\mathrm{km}$ territorial boundary were regularly visited. Frequency increased according to both accessibility and level of distrust with the neighboring community (see Fig. 6). Such distrust was explained by past conflicts. For instance, several decades ago, likely before the mid-1950s when missionaries ended such activities, one woman from Surumaja Gunung was said to have been "stolen" to marry an elder of Metaweja's clan, which started a long-running conflict between Metaweja and Surumaja Gunung. The border between these territories is more than $10 \mathrm{~km}$ long but is close, accessible, and regularly visited, sometimes several times a week. Many gardens and sago groves have been established near this strategic border (Fig. 5b).

In 1994, hunters from the neighbouring Surumaja Gunung community were intercepted while collecting birds of paradise in the Opiye Mountains, in Metaweja territory. These birds are generally shot with air rifles and preserved by drying; a dried bird, in good condition, could be sold to traders for around 1 million IDR (around US\$110) and a living bird could bring as much as 5 million IDR (US\$550). Immediate fines were demanded, a minor struggle ensued, and the hunters escaped without injuries. However, the hunters were recognized, and when the customary leader learned about the incident, he sent a message to the other village naming the intruders. In 2006, another group from Surumaja Gunung was captured in Metaweja territory. A fine of 500,000 IDR per bird (US\$55) was demanded by the customary leader; the hunters lacked money and were allowed to leave without the birds. The fine was never paid, and no collectors have returned.

The 12 young and old male respondents in one focus group discussion claimed to know when a resource or species became scarce or degraded, and indicated that they typically take action by not collecting that resource or species until it recovered; this could be either a personal or a group decision depending on context. More subtle information also influenced such decisions. For example, a wild pig (Sus scrofa) was typically killed every few days: details of the location including the patterns of prints, wallows, nests, leaches, and other signs were examined and reviewed, as was the ease of the hunt and the animal's condition. These details were discussed among all the hunters. Nothing is 
written or recorded, but hunters remember and readily recall significant details and their interpretation. Based on such observations, less productive areas would be rested until the next rainy season. Typically areas are identified in relation to specific streams, rivers, or hills and appear to involve several tens of square kilometers. Such choices improve hunting success and also aid recovery. Discussion with the community indicated that less than one-third of the territory is regularly used for hunting (Fig. 6).

Fig. 6. Map of Metaweja territory showing areas regularly visited for hunting and highlighting the relative frequency per year of boundary visits, based on scoring by the hunters involved (Metaweja men). Rivers and relief are based on terrain data, but boundaries and areas visited are based on handdrawn information.

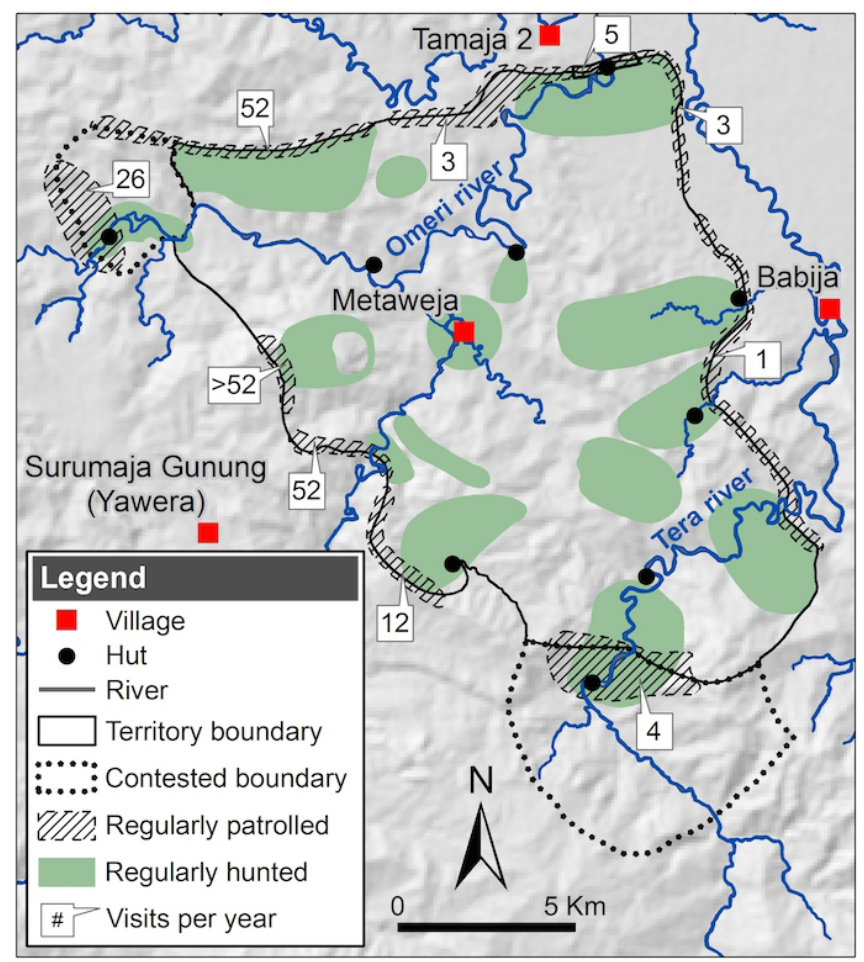

Sanctions were applied to anyone failing to respect controls and the associated norms. For example, the village headman in Metaweja told us that if anyone in the community took too many birds of paradise, they would be asked to stop. If they refused, they could be reported to district officials by radio. This formal control option had never yet been used but is a recognized deterrent primarily because of the implied public shaming.

Several informants noted that fish had been depleted in local rivers because of the use of fine-meshed nylon nets and excessive use of fish poison. Our informants noted that the community had agreed to ban poison, although some people were known to be flouting the ban and continuing to deplete the rivers. Indeed, this seemed to have caused some resentment and animosity. Stronger measures had yet to be taken, although some felt these were needed (MB, informal discussions with communitymembers). Slow progress likely reflects the day-to-day absence of a traditional leader and the fact that fishing was always a minor activity (local rivers are narrow and shallow). It also reflects steady pressure within the community to address such new problems at a pace that balances their severity against a preference to avoid conflict.

\section{Yoke}

Many of Yoke's most valued fishing areas were directly visible from the village (Fig. 5a). One exception was Lake Tabaresia, where one family lives at a strategically selected location overseeing this lake in a role similar to Kay's Ijabaits.

In 2003, a boat from the Bintang Emas company was seen fishing within the village territory and asked to leave; when the crew refused, claiming bad weather, the villagers seized the boat and held it for several days until a company representative arrived. In the meantime the crew was fed and housed in the village. The company representative negotiated with the then village head, and the boat and crew were released. We remain unsure if a fine was paid because apparently this information was never shared with the rest of the community.

The community intercepted another commercial fishing boat in 2011 and warned it to leave. It did.

All villagers collected various resources. The muddy terrain in much of this territory and the necessity of boat access meant tracks were created to access land (Fig. 5d). These tracks were "read" by the villagers, who interpreted what had happened and who was involved. Inappropriate activities were thus hard to conceal. Furthermore, everyone was familiar with resource conditions in the locations they frequented, and community experiences were widely discussed in an informal manner. Collection, fishing, and hunting focused on areas where resources were easily gained. If a resource appeared to be deteriorating, villagers would naturally avoid the areas involved or switch to other resources. We were told that informal processes had been sufficient to manage use and maintain resources, but the community recognized the potential to agree to more formal controls that the whole community would then enforce if needed. When we sought specific examples of such restraint, informants insisted repeatedly that there was no shortage of important resources. For example, wild vegetables, trees used for timber, fish, shellfish, and crabs were still abundant, and people took only what they needed, so the community had never needed to impose any restraints (trade with outsiders remained negligible). When pushed, one group of older men reported that some aquatic species had become harder to find in specific locations, but there was little concern because they remained plentiful elsewhere. These included crocodiles, sharks, turtles, "bandeng" fish (likely Chanos sp.), and "bubara" fish (likely Caranx sp.). Exploring these examples indicated that some of these trends were very local; e. g., the decline in fish abundance was blamed on the dirty water near the village rather than overfishing.

\section{DISCUSSION}

We predicted that established societies in a remote region of Papua (Indonesian New Guinea) would monitor and control their territories and resources. We confirmed this with examples of both territory control and resource assessment in each of the three communities (an area of $3000 \mathrm{~km}^{2}$ ). We and our colleagues have worked with communities in Indonesia and elsewhere, and based 
on various unpublished observations, we believe similar practices occur in most of them. This implies that autonomous monitoring is both widespread and recognizable. For example, previous collaborations with two other Mamberamo communities, Kwerba and Papasena, showed that these communities actively prevented access to the Foja Mountains, although they were willing to grant permission to and support researchers once trust had been earned (Sheil and and Boissière 2006).

Our investigations in three communities show that autonomous monitoring is an integral part of people's lives, livelihoods, and cultures. Autonomous monitoring practices can be focused and general simultaneously. Here, we acknowledge these intrinsic values and their local significance but take a conservation-centric perspective to highlight some wider implications. Specifically we consider researchers' neglect of autonomous monitoring and the implications of improved recognition.

\section{Effectiveness and why autonomous monitoring matters}

Monitoring has emerged as a major theme in resource management and conservation (Sheil 2001, Stem et al. 2005, Gardner 2012). Management must recognize and respond to an ever-changing context. However, monitoring has often become separated from response, with data collection becoming an end in itself (Sheil 2001, Nichols and Williams 2006). In the communities in Papua we see that observation and the potential to respond are closely linked. Virtually all able members of each village, especially the men, are familiar with large regions of the territory. They understand access routes, know the best places to hunt or to camp, and are skilled in assessing their environment and detecting and interpreting signs. These abilities are honed by regular use. People recognize and respond to threats everywhere. Efforts focus on strategic locations, although people also move over large areas and are alert to potential problems.

Autonomous monitoring practices likely play a key role in community resilience and adaptive capacity (in the sense of Miller et al. 2010 and Engle 2011). The ability to recognize and follow up rapidly on anything that attracts attention generates considerable robustness and flexibility, and provides a good basis for learning. The systems will change but as long as people's lives and livelihoods depend on the wider landscapes they inhabit, they are likely to remain intimately engaged with observing and actively protecting it.

Autonomous monitoring processes have limitations. The capacity to identify, deter, or address threats is context dependent. Although our examples suggest restraint is often effective in protecting resources from overharvesting, local problems do arise, such as the depleted fish stocks in Metaweja that had not recovered despite a ban on using fish poison. It appears that inadequate enforcement and/or new fishing methods such as fine mesh nylon nets prevented recovery. Nonetheless, given the discontent voiced by our informants, it seems likely that community disapproval and enforcement will escalate until the problem is addressed.

However, local people cannot identify or address all threats. For example, local people may not know about a regional dam project that will flood their territory or the potential effects of an invasive alien species. Remote communities lack the power required to influence many key decisions that affect them. It is hard to see how Australia's marginalized aboriginal people (discussed in Appendix 1) could have prevented nuclear weapons tests in their territory even if they had known about it (Cane 2002). More typical examples are the timber concessions, mines, and plantations that are often imposed in remote frontier regions without the informed consent of the local people (RobertsonSnape 1999). Negligence, disrespect, opportunism, and deception are symptoms of this power imbalance.

One of us (MB) was working in another Mamberamo community, Kasonaweja, when a clan leader pointed to a new mud road through the forest as part of a new logging concession for the company PT Mamberamo Alas Mandiri, previously known as Kodeko. The leader commented, "This part of our territory is sacred. The company should not encroach. We told them and they agreed. But they encroached anyway. We complained and blocked the road for a while but in the end what else can we do?"We suspect the company may ultimately regret their error. Even where power imbalances appear insurmountable, the victim finds smaller, or sometimes larger, ways to exact justice. This local justice is likely more widespread and costly than generally recognized because those involved are already near invisible to authorities and may actively conceal their actions (Scott 1985).

Although local people are often at a disadvantage against powerful external forces, this is not always the case. At the end of the last century, a couple of years after Indonesia's Suharto regime had ended, companies took advantage of the perceived power vacuum in remote regions. In the territory of Langap Village in Malinau in East Kalimantan, a company began to cut timber within $1 \mathrm{~km}$ of a series of caves where locals collected the nests of swiftlets (Aerodramus spp.) to sell for bird nest soup and other delicacies. The logging broke previously established agreements. The villagers took the law into their own hands and forcibly confiscated the company's vehicles and heavy machinery, refusing to return them until a fine was paid. This cost the company revenue and authority, and acted as a deterrent to other companies in the region (DS, personal observation and various discussions with villagers and local officials). Such incidents may be relatively common: for example, the community of Bau Baru in West Kalimantan was upset by an oil palm company's broken commitments. After various protests, villagers finally drove company machinery into a swamp, thus finally gaining the company's attention to their grievances (Colfer 2001). Such acts target perceived injustices and are double-edged for conservation: both threats to conservation values and conservation itself can trigger resistance if judged illegitimate by the people affected.

Alienation of local people increases the burden on conservation authorities. When protected areas are declared, local people may lose their role as stewards and much of their incentive for caring about sustained resource use. They may even automatically become "illegal" users if they persist with established practices. Defenders may thus be transformed into a perceived menace (Sheil and Boissière 2006). Such alienation can intensify threats to biodiversity and increase conservation costs (Sheil et al. 2013). Estrangement and even hostility often result (e.g., Sharpe 1998, Boissière et al. 2009, Baker et al. 2012). Such outcomes appear tragic and ironic when adversaries had previously shared similar goals: to safeguard the environment and its resources from uncontrolled use. 
Recognition of local monitoring is part of our vision to recognize and support locally conceived conservation (Sheil and Boissière 2006, Sheil et al. 2006, Boissière et al. 2007, 2010, Sassen and Jum 2007, Vermeulen and Sheil 2007b). Conservation that proceeds with local community support has a more ethical foundation for addressing long-term threats. It is also likely to be more sustainable and less costly.

Recognizing how some communities actively protect nature may counterbalance the scepticism that projects seeking to re-establish such local control have often engendered (Blaikie 2006, Larson and Soto 2008, Cox et al. 2010). Such positive examples provide both technical guidance and inspiration, as highlighted by the experience in Pacific Island fisheries (Johannes 2002).

Autonomous monitoring involves various activities undertaken by different people for many reasons. However, without sufficient recognition, the benefits can be lost to ill-conceived interventions that take a uniform approach and leave insufficient opportunity for local norms and practices to be maintained, as observed in many traditional fisheries in Canada and New Zealand (Turner et al. 2013).

\section{Why have they been overlooked?}

Our discussions with colleagues suggest widespread recognition that communities oversee, manage, and protect natural resources in many ways. However, our examination of the literature shows limited formal attention to the degree to which people monitor their environment to protect it. For many the presence of local monitoring is implicit, as in much common property research (Ostrom et al. 1999, Pagdee et al. 2006, Chhatre and Agrawal 2008, Rustagi et al. 2010). Why has more explicit characterization not been attempted?

The lack of attention from conservation professionals and biological scientists, as with other issues of local collaboration, likely reflects disciplinary obstacles related to awareness, credibility, training, rewards, and communication (Sheil and Lawrence 2004). However, many aspects of these autonomous monitoring practices also appear relatively inaccessible to research. For example, consider the age and history of these practices. Most have developed, we assume, over many generations, but we have no way to evaluate this or to assess changes beyond recent decades. Setting aside possible, if unlikely, archaeological insights and detailed reports from earlier travels by outsiders, it is only through a recent innovation, e.g., spotlighting crocodiles, that we can gain a specific insight.

Autonomous monitoring systems are also challenging to describe and characterize. They tend to be integrated with other activities and other goals. Resource maintenance and protection are not necessarily the sole or primary motives. For example, sacred sites are controlled for intangible reasons. Where to monitor is influenced by distrust and past conflict with neighboring communities. Much information gathered about resource status depends on day-to-day activities (e.g., LaRochelle and Berkes 2003). Key aspects are often informal and may operate most effectively where they are most invisible, e.g., in the least accessible places. Shame, with transgressors labeled cheats or incompetents, likely plays a role, but such controls are not readily seen by, or shared with, researchers.
As in many such cross-cultural contexts, researchers and local people may fail in multiple ways to communicate effectively (Sheil and Wunder 2002, Sheil and Lawrence 2004). Our own field experiences revealed various practical challenges in gathering reliable information. Building the necessary trust and ease of communication takes time. Communication can be challenging when discussing abstract concepts and motivations, and information can be contradictory and hard to verify. Candor is not assured. In our own studies, conflicting information generally highlighted uncertainties or misunderstandings rather than wilful efforts to mislead, but even the most cooperative informants may proffer clear information to keep researchers happy rather than admit uncertainties. Cross-validation and repeated checking are key.

A related and, in our experience, more common challenge occurs when informants claim ignorance and inability to help. Sometimes, this is simply shyness and lack of confidence in talking to outsiders; sometimes, they may fear saying something they will regret. Because of their often more limited access to schools, reduced knowledge of Indonesian, and cultural norms, female informants were often less at ease sharing information, including with female researchers. However, in each community they clearly possessed relevant roles, experience, and expertise for their dayto-day practices relating to sites, values, and resources (e.g., the collection of crabs and clams/shells in Yoke). There are no easy solutions. Even if communication obstacles are overcome, the observations gathered by the communities in Papua are hard to assess directly, as with much indigenous knowledge (Agrawal 1995) and even much participatory monitoring (Staddon et al. 2014). The observations are not written. Quantities, when used, are judged rather than measured (such judgments can be highly skilled). The quality and value of such observations depend on context, purpose, and who is making the judgment, and adequacy is demonstrated by the management system's overall effectiveness.

The activities, too, may be difficult to access and characterize. Community members may not wish to explain how and why they check on each other. Such interpersonal politics are hard to explore given the vested interests, conflicts, and distrust potentially involved (Sithole 2002). As recognized in Western cultures, what makes a responsible citizen or a nosy troublemaker is often a question of perspective. There can be reticence or taboos, even shame, in describing internal conflicts to outsiders, while discussing such themes risks (re)igniting conflicts. Even if the researcher is wholly trusted, which seems unlikely, sensitive information may not be shared because of restraints on sharing strategic, privileged, or sensitive knowledge.

Understanding how observations trigger action can be difficult to elucidate given the knowledge, experiences, and beliefs implicitly involved. Furthermore, effectiveness can be hard to demonstrate. Available evidence is often anecdotal and hard to verify, and formal experiments would be difficult and ethically problematic. This is an area requiring further work.

Another practical challenge is to distinguish an effective deterrent from an absence of threat. Much of the effectiveness we see in our Mamberamo communities depends on deterrence. This in turn frequently involves location-specific beliefs and norms in our 
study sites and also elsewhere, e.g., in the supernatural punishments noted in Seram (Sasaoka and Laumonier 2012) and the customary obligations seen in Australia (Cane 2002). In our sites, superstition and taboos remain powerful, with communities believing that transgressors will suffer supernatural punishments that outsiders may ascribe simply to misfortune or bad luck. Metaweja villagers recalled a visit by geologists in 1985 who neglected local permissions and taboos, and cleared vegetation to build a helipad in a sacred area. They cut bamboo and cooked rice in a bamboo stem. According to the informants two of the team died shortly after they left: one was responsible for cutting the bamboo and died from unknown causes, and another had died while bathing when a "small stone entered his head." We were unable to verify any aspect of these events, but the accounts were accepted as demonstrations of supernatural punishments within the communities, and may even give sceptics cause for second thoughts on occasion. However, determining the power of such deterrence in a valid manner remains a challenge.

Our interactions with both locals and outsiders who know the region persuaded us that anyone entering local territories believing them open for exploitation will quickly change their minds. Future study could examine forest resource and land users, including industries and investors, and determine what they seek and what they avoid in terms of community presence.

\section{Looking forward}

Can we be confident that communities will maintain their monitoring activities and continue to contribute to environmental protection? This depends on contexts, options, and motivations. Systems are flexible and can be influenced when it is useful. For example, lights provide an effective way to assess crocodiles. Kay's crocodile hunters also adopted size restrictions, and when the markets changed, they turned to other resources.

There is no reason to expect only positive outcomes. For example, an increasingly cash-based economy, resource commercialization, access to more efficient harvesting technologies, and changing aspirations and perceptions may all pose challenges. Some monitoring activities may decline as conflicts decline and as trust increases. For example, the Dani watchtowers of the Baliem Valley (also in Papua, Indonesian New Guinea) once indicated the vigilance with which communities observed each other in a culture of frequent small-scale raids (Gardner and Heider 1968). Such watchtowers were costly to build, maintain, and operate, and no longer exist because there is little need for them. In Mamberamo, too, mistrust among communities ensures vigilance. However, although increased trust may reduce policing efforts and likelihood of incursions in some locations, such efforts may decline or be expended more evenly across the territory depending on motivations.

Recognizing local activities that contribute to conservation outcomes has unexplored implications. Here we have focused on the value and significance of autonomous monitoring and control processes primarily in terms of their local significance and their implications for those interested in achieving environmental conservation and the protection of biodiversity. We are wary of implying that the value of these long-neglected systems lies primarily in how we might be able to use them. That is not our view. The potential to adapt these systems was not the subject of our study. Nonetheless, when considering possible synergies with external interests, the options include how communities might participate in and contribute to externally overseen conservation (Cooke and Kothari 2001, Sheil and Lawrence 2004, Sayer et al. 2013) or natural resource monitoring (e.g., Guijt 2007, Danielsen et al. 2009, Staddon et al. 2014), including the various activities involved in monitoring as well as Measurement, Reporting and Verification of Reducing Emissions from Deforestation and forest Degradation (REDD) or payment-for-environmental-services schemes (Boissière et al. 2014, Torres et al. 2014, Torres and Skutsch 2015). Just as importantly, we can invert the question and consider when and how external conservation interests can contribute to existing community efforts.

In an ideal world we would leave these local practices alone, at least if that is what the community wanted. However, in a world where threats change, grow, and diversify, external agencies may sometimes be able to play a vital role. Rather than replacing local management systems, we should seek ways to support them. The benefits of local monitoring are provided free to the world; bolstering these schemes would help sustain these benefits. Opportunities for cooperation may also exist where objectives align (Vermeulen and Sheil 2007a, Berkes 2010, Sayer et al. 2013). Communities are not always able to address all the challenges confronting them, as when miners encroached on the Amazon's Kayapó territories (see Schwartzman and Zimmerman 2005). Such shortfalls may sometimes be addressed through building active collaboration with outside agencies.

There is a considerable need for basic research to recognize how communities may cover the shortfall where government authorities are generally overstretched and unable to effectively manage the areas for which they are responsible. We suspect such situations are common. We won't know until we look.

Equally, we know nearly as little about community actions in situations where governments and others have imposed authority and claimed oversight. There is potential for both synergy and conflict. We speculate that such circumstances may result in the modification and coexistence of autonomous systems as well as replacement and loss of the autonomous systems.

Given autonomous protection of land, water, and resources, and the limitations of official bodies in performing a similar function, coexistence seems desirable. There must be ways that the strengths of each approach can work in synergy. Communities would manage and protect against local threats, while governments and others would provide assistance when required and focus on larger scale challenges. Achieving such outcomes will require effort: such an effort depends on a wider acknowledgement of both the problem and the solution.

\section{CONCLUSIONS}

We call for greater attention to autonomous monitoring. Such monitoring and control may still dominate in many regions of the world where external authorities lack day-to-day oversight. These systems have limits, and many pertinent questions remain unanswered. We encourage a respectful case-by-case examination to understand the extent, significance, and effectiveness of community activities, from the perspective of the community as well as our own. What are their strengths and weaknesses? How, and in what contexts, might we protect and support them? Whether autonomous monitoring is widespread and effective, or 
rare and ineffective, we need to recognize not only when local people are willing to champion environmental causes, but also when they are already doing so. The potential tragedy of the unseen sentinels is that so much may be lost simply because we failed to open our eyes to look.

Responses to this article can be read online at: http://www.ecologyandsociety.org/issues/responses. $\mathrm{php} / 7625$

\section{Acknowledgments:}

We thank the communities of Kay, Metaweja, and Yoke in Mamberamo Raya for their participation, assistance, patience, and hospitality. We thank Teresia Yeuw, Michael Padmanaba (Center for International Forestry Research; CIFOR), and others team members who collected data, and Serge Rafanoharana (CIFOR), Agus Mohammad Salim (CIFOR), and Hendi Sumantri (Conservation International) for their assistance in generating maps. We acknowledge the l'Agence Française pour le Développement ( $A F D$ ) for their financial support to the project Collaborative Land Use Planning in Papua (COLUP) and to the U.S. Agency for International Development (USAID) and the Norwegian Agency for Development (NORAD) for their financial support of the research project Participatory Measuring, Reporting and Verifying (PMRV). DS's work with CIFOR was supported by the European Commission. This research was carried out by CIFOR and the Centre de coopération Internationale en Recherche Agronomique pour le Développement (CIRAD), as part of the CGIAR Research Program on Forests, Trees and Agroforestry. We are grateful to Carol Colfer, Claire Miller, and two referees for many helpful comments on an earlier draft of this paper.

\section{LITERATURE CITED}

Agrawal, A. 1995. Dismantling the divide between indigenous and scientific knowledge. Development and Change 26(3):413-439. http://dx.doi.org/10.1111/j.1467-7660.1995.tb00560.x

Baker, J., E. J. Milner-Gulland, and N. Leader-Williams. 2012. Park gazettement and integrated conservation and development as factors in community conflict at Bwindi Impenetrable Forest, Uganda. Conservation Biology 26(1):160-170. http://dx.doi. org/10.1111/j.1523-1739.2011.01777.x

Basuki, I., D. Sheil, M. Padmanaba, N. Liswanti, G. Mulcahy, and M. Wan. 2011. The evolving role of tropical forests for local livelihoods in Indonesia. International Journal of Environment and Sustainable Development 10(3):267-287. http://dx.doi.org/10.1504/ ijesd.2011.045367

Berkes, F. 2010. Devolution of environment and resources governance: trends and future. Environmental Conservation 37 (4):489-500. http://dx.doi.org/10.1017/s037689291000072x

Berkes, F., J. Colding, and C. Folke. 2000. Rediscovery of traditional ecological knowledge as adaptive management. Ecological Applications 10(5):1251-1262. http://dx.doi. org/10.1890/1051-0761(2000)010[1251:roteka]2.0.co;2

Berkes, F., C. Folke, and J. Colding, editors. 1998. Linking social and ecological systems: management practices and social mechanisms for building resilience. Cambridge University Press, Cambridge, UK.

Blaikie, P. 2006. Is small really beautiful? Community-based natural resource management in Malawi and Botswana. World Development 34(11):1942-1957. http://dx.doi.org/10.1016/j. worlddev.2005.11.023

Boissière, M., G. Beaudoin, C. Hofstee, and S. Rafanoharana. 2014. Participating in REDD+ Measurement, Reporting, and Verification (PMRV): opportunities for local people? Forests 5 (8):1855-1878. http://dx.doi.org/10.3390/f5081855

Boissière, M., N. Liswanti, M. Padmanaba, and D. Sheil. 2007. People priorities and perceptions: towards conservation partnership in Mamberamo. Project report. Center for International Forestry Research, Bogor, Indonesia. [online] URL: http://www.cifor.org/library/3123/people-priorities-and-perceptionstowards-conservation-partnership-in-mamberamo/

Boissière, M., B. Locatelli, D. Sheil, M. Padmanaba, and E. Sadjudin. 2013. Local perceptions of climate variability and change in tropical forests of Papua, Indonesia. Ecology and Society 18(4): 13. http://dx.doi.org/10.5751/es-05822-180413

Boissière, M., M. Sassen, D. Sheil, M. Heist, W. Jong, R. Cunliffe, M. Wan, M. Padmanaba, N. Liswanti and I. Basuki. 2010. Researching local perspectives on biodiversity in tropical landscapes: lessons from ten case studies. Pages 113-141 in A. Lawrence, editor. Taking stock of nature: participatory biodiversity assessment for policy, planning and practice. Cambridge University Press, Cambridge, UK. http://dx.doi.org/10.1017/cbo9780511676482.006

Boissière, M., D. Sheil, I. Basuki, M. Wan, and H. Le. 2009. Can engaging local people's interests reduce forest degradation in Central Vietnam? Biodiversity and Conservation 18(10):2743-2757. http://dx.doi.org/10.1007/s10531-009-9627-1

Boissière, M., M. van Heist, D. Sheil, I. Basuki, S. Frazier, U. Ginting, M. Wan, B. Hariadi, H. Hariyadi, H. D. Kristianto, et al. 2006. Pentingnya sumberdaya alam bagi masyarakat lokal di daerah aliran Sungai Mamberamo, Papua, dan implikasinya bagi konservasi. Journal of Tropical Ethnobiology 1(2):76-95.

Brooks, T. M., S. J. Wright, and D. Sheil. 2009. Evaluating the success of conservation actions in safeguarding tropical forest biodiversity. Conservation Biology 23(6):1448-1457. http://dx.doi. org/10.1111/j.1523-1739.2009.01334.X

Bruner, A. G., R. E. Gullison, R. E. Rice, and G. A. B. da Fonseca. 2001. Effectiveness of parks in protecting tropical biodiversity. Science 291(5501):125-128. http://dx.doi.org/10.1126/science.291.5501.125

Cane, S. 2002. Pila Nguru: the Spinifex people. Fremantle Art Centre Press, Fremantle, Western Australia.

Chape, S., J. Harrison, M. Spalding, and I. Lysenko. 2005. Measuring the extent and effectiveness of protected areas as an indicator for meeting global biodiversity targets. Philosophical Transactions of the Royal Society B: Biological Sciences 360 (1454):443-455. http://dx.doi.org/10.1098/rstb.2004.1592

Chhatre, A., and A. Agrawal. 2008. Forest commons and local enforcement. Proceedings of the National Academy of Sciences of the United States of America 105(36):13286-13291. http://dx.doi. org/10.1073/pnas.0803399105 
Colding, J., and C. Folke. 2001. Social taboos: "invisible" systems of local resource management and biological conservation. Ecological Applications 11(2):584-600.

Colfer, C. J. P. 2001. Fire in East Kalimantan: a panoply of practices, views and (discouraging) effects. Borneo Research Bulletin 32:32-56.

Contreras-Hermosilla, A. 2002. Law compliance in the forestry sector: an overview. World Bank, Washington, D.C., USA.

Cooke, B., and U. Kothari. 2001. Participation: the new tyranny? Zed Books, London, UK.

Cox, J. 1992. Development of the crocodile industry on a sustainable basis. Terminal Report FAO-PHPA Project. Food and Agriculture Organization of the United Nations, Rome, Italy.

Cox, M., G. Arnold, and S. Villamayor Tomás. 2010. A review of design principles for community-based natural resource management. Ecology and Society 15(4): 38. [online] URL: http:// www.ecologyandsociety.org/vol15/iss4/art38/

Danielsen, F., N. D. Burgess, A. Balmford, P. F. Donald, M. Funder, J. P. Jones, P. Alviola, D. S. Balete, T. Blomley, J. Brashares, et al. 2009. Local participation in natural resource monitoring: a characterization of approaches. Conservation Biology 23(1):31-42. http://dx.doi.org/10.1111/j.1523-1739.2008.01063. $\underline{x}$

Danielsen, F., P. M. Jensen, N. D. Burgess, I. Coronado, S. Holt, M. K. Poulsen, R. M. Rueda, T. Skielboe, M. Enghoff, L. H. Hemmingsen, et al. 2014a. Testing focus groups as a tool for connecting indigenous and local knowledge on abundance of natural resources with science-based land management systems. Conservation Letters 7(4):380-389. http://dx.doi.org/10.1111/ conl.12100

Danielsen, F., K. Pirhofer-Walzl, T. P. Adrian, D. R. Kapijimpanga, N. D. Burgess, P. M. Jensen, R. Bonney, M. Funder, A. Landa, N. Levermann, et al. 2014b. Linking public participation in scientific research to the indicators and needs of international environmental agreements. Conservation Letters 7 (1):12-24. http://dx.doi.org/10.1111/conl.12024

Departmen Kehutanan [Forestry Department]. 2010. Statistik tahun 2009 [statistics for the year 2009]. Balai Besar Konservasi Sumber Daya Alam Papua, Departmen Kehutanan, Jayapura, Papua, Indonesia.

Engle, N. L. 2011. Adaptive capacity and its assessment. Global Environmental Change 21(2):647-656. http://dx.doi.org/10.1016/ j.gloenvcha.2011.01.019

Frazier, S. 1988. Mamberamo river crocodile monitoring patrol in the Pagai area. Food and Agriculture Organization of the United Nations, Jayapura, Papua, Indonesia.

Galinato, G. I., and S. P. Galinato. 2013. The short-run and longrun effects of corruption control and political stability on forest cover. Ecological Economics 89:153-161. http://dx.doi.org/10.1016/ j.ecolecon.2013.02.014

Gardner, R., and K. G. Heider. 1968. Gardens of war. Random House, New York, New York, USA.
Gardner, T. 2012. Monitoring forest biodiversity: improving conservation through ecologically-responsible management: Routledge, Abingdon, UK.

Guijt, I. 2007. Negotiated learning: collaborative monitoring in forest resource management. Resources For the Future, Washington, D.C., USA.

Hellier, A., A. C. Newton, and S. O. Gaona. 1999. Use of indigenous knowledge for rapidly assessing trends in biodiversity: a case study from Chiapas, Mexico. Biodiversity \& Conservation 8(7):869-889. http://dx.doi.org/10.1023/A:1008862005556

Johannes, R. E. 2002. The renaissance of community-based marine resource management in Oceania. Annual Review of Ecology and Systematics 33:317-340. http://dx.doi.org/10.1146/ annurev.ecolsys.33.010802.150524

Keim, A. P. 2012. The pandan flora of Foja-Mamberamo Game Reserve and Baliem Valley, Papua-Indonesia. Reinwardtia 13 (3):271-297.

LaRochelle, S., and F. Berkes. 2003. Traditional ecological knowledge and practice for edible wild plants: biodiversity use by the Rarámuri, in the Sirerra Tarahumara, Mexico. International Journal of Sustainable Development \& World Ecology 10 (4):361-375. http://dx.doi.org/10.1080/13504500309470112

Larson, A. M., and F. Soto. 2008. Decentralization of natural resource governance regimes. Annual Review of Environment and Resources 33(1):213. http://dx.doi.org/10.1146/annurev. environ.33.020607.095522

Lund, J. F., K. Balooni, and L. Puri. 2010. Perception-based methods to evaluate conservation impact in forests managed through popular participation. Ecology and Society 15(3): 5. [online] URL: http://www.ecologyandsociety.org/vol15/iss3/art5

Marshall, A. J., and B. M. Beehler. 2007. The ecology of Papua. Periplus Editions, Singapore.

McCarthy, D. P., P. F. Donald, J. P. W. Scharlemann, G. M. Buchanan, A. Balmford, J. M. H. Green, L. A. Bennun, N. D. Burgess, L. D. C. Fishpool, S. T. Garnett, et al. 2012. Financial costs of meeting global biodiversity conservation targets: current spending and unmet needs. Science 338(6109):946-949. http://dx. doi.org/10.1126/science. 1229803

McCreless, E., P. Visconti, J. Carwardine, C. Wilcox, and R. J. Smith. 2013. Cheap and nasty? The potential perils of using management costs to identify global conservation priorities. PLoS One 8(11):e80893. http://dx.doi.org/10.1371/journal. pone. 0080893

Miller, F., H. Osbahr, E. Boyd, F. Thomalla, S. Bharwani, G. Ziervogel, B. Walker, J. Birkmann, S. van der Leeuw, J. Rockström, et al. 2010. Resilience and vulnerability: complementary or conflicting concepts. Ecology and Society 15(3): 11. [online] URL: http://www.ecologyandsociety.org/vol15/iss3/art11/

Molnar, A., S. J. Scherr, and A. Khare. 2004. Who conserves the world's forests? Community-driven strategies to protect forests and respect rights. Policy Brief. Forest Trends, Washington, D.C., USA. [online] URL: http://www.forest-trends.org/publication details. php?publicationID $=384$ 
Nichols, J. D., and B. K. Williams. 2006. Monitoring for conservation. Trends in Ecology \& Evolution 21(12):668-673. http://dx.doi.org/10.1016/j.tree.2006.08.007

Normile, D. 2010. Saving forests to save biodiversity. Science 329 (5997):1278-1280. http://dx.doi.org/10.1126/science.329.5997.1278

Oliver, P. M., S. M. Richards, and B. Tjaturadi. 2012. Two new species of Callulops (Anura: Microhylidae) from montane forests in New Guinea. Zootaxa 3178:33-44.

Ostrom, E. 1990. Governing the commons: the evolution of institutions for collective action. Political Economy of Institutions and Decisions. Cambridge University Press, Cambridge, UK. http://dx.doi.org/10.1017/cbo9780511807763

Ostrom, E., J. Burger, C. B. Field, R. B. Norgaard, and D. Policansky. 1999. Revisiting the commons: local lessons, global challenges. Science 284(278):278-282. http://dx.doi.org/10.1126/ science.284.5412.278

Padmanaba, M., M. Boissière, Ermayanti, H. Sumantri, and R. Achdiawan. 2012. Perspectives on collaborative land use planning in Mamberamo Raya Regency, Papua, Indonesia: case studies from Burmeso, Kwerba, Metaweja, Papasena, and Yoke. Project Report. Center for International Forestry Research, Bogor, Indonesia. [online] URL: http://www.cifor.org/mla/download/publication/ Mamberamo en web.pdf

Padmanaba, M., D. Sheil, I. Basuki, and N. Liswanti. 2013. Accessing local knowledge to identify where species of conservation concern occur in a tropical forest landscape. Environmental Management 52(2):348-359. http://dx.doi.org/10.1007/ $\underline{\mathrm{s} 00267-013-0051-7}$

Pagdee, A., Y.-S. Kim, and P. Daugherty. 2006. What makes community forest management successful: a meta-study from community forests throughout the world. Society and Natural Resources 19(1):33-52. http://dx.doi.org/10.1080/08941920500323260

Rencana Tata Ruang Wilayah (RTRW). 2009. Kabupaten Mamberamo Raya Tahun 2009-2029 Provinsi Papua-Laporan akhir. PT. Karsa Utama Bumisaka, Jakarta, Indonesia.

Richards, S. J., and S. Suryadi, editors. 2002. A biodiversity assessment of Yongsu-Cyclops Mountains and the Southern Mamberamo Basin, Papua, Indonesia. RAP Bulletin of Biological Assessment 25. Conservation International, Washington, D.C., USA.

Ricketts, T. H., E. Dinerstein, T. Boucher, T. M. Brooks, S. H. M. Butchart, M. Hoffmann, J. F. Lamoreux, J. Morrison, M. Parr, J. D. Pilgrim, et al. 2005. Pinpointing and preventing imminent extinctions. Proceedings of the National Academy of Sciences of the United States of America 102(51):18497-18501. http://dx.doi. org/10.1073/pnas.0509060102

Robertson-Snape, F. 1999. Corruption, collusion and nepotism in Indonesia. Third World Quarterly 20(3):589-602. http://dx.doi. org/10.1080/01436599913703

Rodrigues, A. S. L., H. R. Akçakaya, S. J. Andelman, M. I. Bakarr, L. Boitani, T. M. Brooks, J. S. Chanson, L. D. C. Fishpool, G. A. B. da Fonseca, K. J. Gaston, et al. 2004. Global gap analysis: priority regions for expanding the global protected-area network. BioScience 54(12):1092-1100. http://dx.doi.org/10.1641/0006-3568 (2004)054[1092:ggaprf]2.0.co:2
Rustagi, D., S. Engel, and M. Kosfeld. 2010. Conditional cooperation and costly monitoring explain success in forest commons management. Science 330(6006):961-965. http://dx. doi.org/10.1126/science.1193649

Sasaoka, M., and Y. Laumonier. 2012. Suitability of local resource management practices based on supernatural enforcement mechanisms in the local social-cultural context. Ecology and Society 17(4): 6. http://dx.doi.org/10.5751/ ES-05124-170406

Sassen, M., and C. Jum. 2007. Assessing local perspectives in a forested landscape of central Cameroon. Forests, Trees and Livelihoods 17(1):23-42. http://dx.doi.org/10.1080/14728028.2007.9752579

Sayer, J., T. Sunderland, J. Ghazoul, J.-L. Pfund, D. Sheil, E. Meijaard, M. Venter, A. K. Boedhihartono, M. Day, C. Garcia, et al. 2013. Ten principles for a landscape approach to reconciling agriculture, conservation, and other competing land uses. Proceedings of the National Academy of Sciences of the United States of America 110(21):8349-8356. http://dx.doi.org/10.1073/ pnas. 1210595110

Scholte, P., and W. T. De Groot. 2010. From debate to insight: three models of immigration to protected areas. Conservation Biology 24(2):630. http://dx.doi.org/10.1111/j.1523-1739.2009.01314. $\underline{\mathrm{X}}$

Schwartzman, S., and B. Zimmerman. 2005. Conservation alliances with indigenous peoples of the Amazon. Conservation Biology 19(3):721-727. http://dx.doi.org/10.1111/j.1523-1739.2005.00695. $\underline{\mathrm{X}}$

Scott, J. 1985. Weapons of the weak: everyday forms of peasant resistance. Yale University Press, New Haven, Connecticut, USA.

Sharpe, B. 1998. 'First the forest': conservation, 'community' and 'participation' in south-west Cameroon. Africa 68(1):25-45. http://dx.doi.org/10.2307/1161146

Sheil, D. 2001. Conservation and biodiversity monitoring in the tropics: realities, priorities, and distractions. Conservation Biology 15(4):1179-1182. http://dx.doi.org/10.1046/j.1523-1739.2001.0150041179. $\underline{x}$

Sheil, D., and M. Boissière. 2006. Local people may be the best allies in conservation. Nature 440(7086):868-868. http://dx.doi. org/10.1038/440868d

Sheil, D., and A. Lawrence. 2004. Tropical biologists, local people and conservation: new opportunities for collaboration. Trends in Ecology \& Evolution 19(12):634-638. http://dx.doi.org/10.1016/j. tree.2004.09.019

Sheil, D., and N. Liswanti. 2006. Scoring the importance of tropical forest landscapes with local people: patterns and insights. Environmental Management 38(1):126-136. http://dx.doi.org/10.1007/ $\underline{\mathrm{s} 00267-005-0092-7}$

Sheil, D., E. Meijaard, A. Angelsen, J. Sayer, and J. K. Vanclay. 2013. Sharing future conservation costs. Science 339 (6117):270-271. http://dx.doi.org/10.1126/science.339.6117.270b

Sheil, D., R. K. Puri, I. Basuki, M. van Heist, M. Wan, N. Liswanti, E. Permana, E. M. Angi, F. Gatzweiler, and B. Johnson. 2002. Exploring biological diversity, environment and local people's 
perspectives in forest landscapes: methods for a multidisciplinary landscape assessment. Center for International Forestry Research, Jakarta, Indonesia. [online] URL: http://www.cifor.org/ library/1021/exploring-biological-diversity-environment-and-localpeoples-perspectives-in-forest-landscapes-methods-for-a-multidisciplinarylandscape-assessment/

Sheil, D., R. Puri, M. Wan, I. Basuki, M. van Heist, N. Liswanti, Rukmiyati, I. Rachmatika, and I. Samsoedin. 2006. Recognizing local people's priorities for tropical forest biodiversity. Ambio 35 (1):17-24. http://dx.doi.org/10.1579/0044-7447-35.1.17

Sheil, D., and S. Wunder. 2002. The value of tropical forest to local communities: complications, caveats, and cautions. Conservation Ecology 6(2):9.

Sithole, B. 2002. Where the power lies: multiple stakeholder politics over natural resources: a participatory methods guide. Center for International Forestry Research, Jakarta, Indonesia.

Smith, E. A., and M. Wishnie. 2000. Conservation and subsistence in small-scale societies. Annual Review of Anthropology 29:493-524. http://dx.doi.org/10.1146/annurev.anthro.29.1.493

Solomon, J., S. K. Jacobson, K. D. Wald, and M. Gavin. 2007. Estimating illegal resource use at a Ugandan park with the randomized response technique. Human Dimensions of Wildlife 12(2):75-88. http://dx.doi.org/10.1080/10871200701195365

Staddon, S. C., A. Nightingale, and S. K. Shrestha. 2014. The social nature of participatory ecological monitoring. Society \& Natural Resources 27(9):899-914. http://dx.doi.org/10.1080/08941920.2014.905897

Stem, C., R. Margoluis, N. Salafsky, and M. Brown. 2005. Monitoring and evaluation in conservation: a review of trends and approaches. Conservation Biology 19(2):295-309. http://dx. doi.org/10.1111/j.1523-1739.2005.00594.x

Takeuchi, W. 2009. Ardisia hymenandroides (Myrsinaceae), an unusual monoaxial species from the Foja Mountains of West New Guinea. Harvard Papers in Botany 14(2):167-172. http://dx.doi. org/10.3100/025.014.0208

Torres, A. B., L. A. S. Acuña, and J. M. C. Vergara. 2014. Integrating $\mathrm{CBM}$ into land-use based mitigation actions implemented by local communities. Forests 5(12):3295-3326. http://dx.doi.org/10.3390/f5123295

Torres, A. B., and M. Skutsch. 2015. The potential role for community monitoring in MRV and in benefit sharing in REDD+. Forests 6(1):244-251. http://dx.doi.org/10.3390/ f6010244

Turner, N. J., F. Berkes, J. Stephenson, and J. Dick. 2013. Blundering intruders: extraneous impacts on two indigenous food systems. Human Ecology 41(4):563-574. http://dx.doi.org/10.1007/ s10745-013-9591-y

van Heist, M., D. Sheil, I. Rachman, P. Gusbager, C. O. Raweyai, and H. S. M. Yoteni. 2010. The forests and related vegetation of Kwerba, on the Foja Foothills, Mamberamo, Papua (Indonesian New Guinea). Blumea 55(2):153-161. http://dx.doi. org/10.3767/000651910x526889
Vermeulen, S., and D. Sheil. 2007a. Partnerships for tropical conservation. Oryx 41(4):434-440. http://dx.doi.org/10.1017/ $\underline{\mathrm{S} 0030605307001056}$

Vermeulen, S., and D. Sheil. 2007b. The possibility of common ground: a reply to Mavhunga and Robinson. Oryx 41(4):445-446. http://dx.doi.org/10.1017/S0030605307414910

Wadley, R. L., and C. J. P. Colfer. 2004. Sacred forest, hunting, and conservation in West Kalimantan, Indonesia. Human Ecology 32(3):313-338. http://dx.doi.org/10.1023/b: huec.0000028084.30742.d0 


\section{Appendix 1}

This appendix summarizes published literature relating to autonomous monitoring by people deriving their livelihood largely from wild species in tropical regions.

Our ISI keyword search (see methods) provided several hundred hits. Most dealt with healthcare or with citizen science within Western industrial societies and were thus excluded. When titles and abstracts were reviewed for possible relevant papers, 23 were examined in full text, with a further 33 texts of interest identified from the citations also examined. Only two of these 56 texts met our criteria by describing autonomous processes relevant to conservation in a tropical context. Of these, only one explicitly considers such monitoring in practice (LaRochelle and Berkes 2003) while the other recognizes their existence but lacks examples (Danielsen et al. 2009) but see also (Danielsen et al. 2014). From our own readings, and the suggestions of two reviewers, we have identified further cases that place our observations in a broader context. Most examples are implicit rather than explicit.

Several temperate or boreal examples do offer useful insights that may have wider applicability (Moller et al. 2004). However, these are mainly pre-occupied with collaboration and participatory approaches which is not our focus here.

Regulations, sanctions and self-policing are part of communal management and feature as a key element in the common property literature (Ostrom 1990, Ostrom et al. 1999, Berkes 2010). Studies indicate that autonomous policing and enforcement help avoid excessive exploitation of shared resources (Chhatre and Agrawal 2008, Rustagi et al. 2010) and that increased monitoring and sanctioning are associated with less resource degradation (Pagdee et al. 2006). Most discussion focuses on principles rather than the technical details that might normally be applied to discussions of monitoring. For example, members of some Swiss Alpine communities police common areas and can impose fines on other members when accepted rules are violated (Casari and Plott 2003).

Common-property self-monitoring can produce surprising implications. For example, in one case-study community members in Zimbabwe were concerned that valuable grass (used for commercial broom-making) was being degraded and overharvested. 
The community themselves suggested, among other things, to increase, not decrease, the number of households accessing and thus benefitting from this declining resource - the view was that if more people benefitted there would be more observers intolerant of damaging practices (Vanclay 2010).

Outside the common property literature examples of autonomous monitoring practices are harder to find - largely because they are not readily identified with key words or summaries.

Pacific islanders often practice various measures to prevent the overharvesting of marine resources (Johannes 2002, Jupiter et al. 2014). Measures often include controlled access and the enforcement of no take zones and/or seasons. For example 27 out of 27 villages interviewed in Vanuatu prohibited exploitation of local marine resources by outsiders without permission, and many had established local bans on exploiting specific sites, or species, or using certain harvest methods (Johannes 1998). The effectiveness of these measures has led to recognition, encouragement, and renaissance in such management (Johannes 2002). Our own reading of this literature provides many examples of the principles being applied but few details of how rules are enforced.

We find examples in the literature that address monitoring without using the term. For example, in Seram, Indonesia, the forest is traditionally divided into parcels owned by families who have exclusive rights for gathering resources and hunting. The owners rest parcels when resources appear depleted. During these rest periods the parcel owners may observe evidence of illicit use (Sasaoka and Laumonier 2012). In these cases the land owner claims to know, based on the evidence, who is responsible. The alleged wrongdoer is not confronted, but the allegations are shared discreetly within the community, and any subsequent misfortune that befalls the purported perpetrator or their family is interpreted as supernatural punishment (Sasaoka and Laumonier 2012). While accurately described as an example of supernatural involvement in management (Sasaoka and Laumonier 2012), it also relies, albeit implicitly, on the repeated observations that lead to resting land and identifying illicit use. 
A typical account of how resource users interact with their environment is provided by LaRochelle and Berkes (2003) who studied the management of wild forest food plants by the Raramuri people of Chihuahua State in Mexico and commented that resource monitoring was part of "daily activities, such as gathering livestock, collecting fuel wood, or harvesting plants ... participants noted that to monitor the state of edible plants, people must harvest and use them".

Another example: in the deserts of Western Australia the aboriginal "Spinifex People" considered land to be sacred. Each community member learned the complex mythology tying them and their ancestors to specific locations and territories with associated rules, roles, rights and responsibilities. Only close family freely enter another's territory without permission. Roles and responsibilities include site protection (Cane 2002). For example, certain waterholes can only be accessed by specific men who manage the surrounding vegetation and keep the water clean (no one else can draw water, but in droughts they may gain permission to camp nearby and have water carried to them). Punishments for transgressions were historically severe, but for most the fear and shame were sufficient deterrent. Local knowledge, tracking skills and rapid action provided effective control over a vast region: in 1995 for example, some elders intercepted a group of unauthorized geologists who were guided off the territory and told not to return (Cane 2002). Again nothing in this account identified the activities as monitoring.

Evolutionary psychology suggests that self-policing has molded our behaviors (Fehr and Gächter 2000, Rand and Nowak 2013). Examples include human interest in what others are doing, willingness to punish, and the influence of observation (Haley and Fessler 2005, Bernhard et al. 2006, Powell et al. 2012, Miyazaki 2013, Nettle et al. 2013).

\section{LITERATURE CITED}

Berkes, F. 2010. Devolution of environment and resources governance: trends and future. Environmental Conservation 37:489-500.

Bernhard, H., U. Fischbacher, and E. Fehr. 2006. Parochial altruism in humans. Nature 442:912-915.

Cane, S. 2002. Pila Nguru: the Spinifex People. Fremantle Art Centre Press, Fremantle, Western Australia. 
Casari, M. and C. R. Plott. 2003. Decentralized management of common property resources: experiments with a centuries-old institution. Journal of Economic Behavior \& Organization 51:217-247.

Chhatre, A. and A. Agrawal. 2008. Forest commons and local enforcement. Proceedings of the National Academy of Sciences 105:13286-13291.

Danielsen, F., N. D. Burgess, A. Balmford, P. F. Donald, M. Funder, J. P. Jones, P. Alviola, D. S. Balete, T. Blomley, and J. Brashares. 2009. Local participation in natural resource monitoring: a characterization of approaches. Conservation Biology 23:3142.

Danielsen, F., K. Pirhofer-Walzl, T. P. Adrian, D. R. Kapijimpanga, N. D. Burgess, P. M. Jensen, R. Bonney, M. Funder, A. Landa, and N. Levermann. 2014. Linking public participation in scientific research to the indicators and needs of international environmental agreements. Conservation Letters 7:12-24.

Fehr, E. and S. Gächter. 2000. Cooperation and punishment in public goods experiments. American Economic Review 90:980-994.

Haley, K. J. and D. M. T. Fessler. 2005. Nobody's watching?: Subtle cues affect generosity in an anonymous economic game. Evolution and Human Behavior 26:245-256.

Johannes, R. 1998. Government-supported, village-based management of marine resources in Vanuatu. Ocean \& coastal management 40:165-186.

Johannes, R. E. 2002. The renaissance of community-based marine resource management in Oceania. Annual Review of Ecology and Systematics:317-340.

Jupiter, S. D., P. J. Cohen, R. Weeks, A. Tawake, and H. Govan. 2014. Locally-managed marine areas: multiple objectives and diverse strategies. Pacific Conservation Biology 20:165-179.

LaRochelle, S. and F. Berkes. 2003. Traditional ecological knowledge and practice for edible wild plants: Biodiversity use by the Rarámuri, in the Sirerra Tarahumara, Mexico. The International Journal of Sustainable Development \& World Ecology 10:361-375.

Miyazaki, Y. 2013. Increasing visual search accuracy by being watched. PloS one 8.

Moller, H., F. Berkes, P. O. B. Lyver, and M. Kislalioglu. 2004. Combining science and traditional ecological knowledge: monitoring populations for co-management. Ecology and Society 9:2.

Nettle, D., Z. Harper, A. Kidson, R. Stone, I. S. Penton-Voak, and M. Bateson. 2013. The watching eyes effect in the Dictator Game: it's not how much you give, it's being seen to give something. Evolution and Human Behavior 34:35-40.

Ostrom, E. 1990. Governing the commons: The evolution of institutions for collective action (political economy of institutions and decisions). Cambridge University Press, Cambridge, UK.

Ostrom, E., J. Burger, C. B. Field, R. B. Norgaard, and D. Policansky. 1999. Revisiting the commons: local lessons, global challenges. Science 284:278-282.

Pagdee, A., Y.-s. Kim, and P. Daugherty. 2006. What makes community forest management successful: a meta-study from community forests throughout the world. Society and Natural Resources 19:33-52.

Powell, K. L., G. Roberts, and D. Nettle. 2012. Eye images increase charitable donations: evidence from an opportunistic field experiment in a supermarket. Ethology 118:10961101.

Rand, D. G. and M. A. Nowak. 2013. Human cooperation. Trends in Cognitive Sciences 17:413-425.

Rustagi, D., S. Engel, and M. Kosfeld. 2010. Conditional cooperation and costly monitoring explain success in forest commons management. Science 330:961-965. 
Sasaoka, M. and Y. Laumonier. 2012. Suitability of local resource management practices based on supernatural enforcement mechanisms in the local social-cultural context. Ecology and Society 17:6.

Vanclay, J. K. 2010. Participatory modelling to inform rural development: case studies from Zimbabwe and Australia. International Journal of Environmental and Rural Development 1:122-126. 


\section{Appendix 2}

This appendix provides a more comprehensive description of the communities and their livelihood context.

Kay: Most of the territory is level and seasonally flooded but there is steeper terrain reaching to about $350 \mathrm{~m}$ a.s.I. in the north. Valued resources included sago (Metroxylon sagu), rattan (various species Calamus spp., Daemonorops, spp. and perhaps Korthalsia spp.), crocodile (Crocodylus novaeguineae and $C$. porosus), fish (various marine and fresh water species), wild pigs (Sus scrofa), cassowaries (Casuarius unappendiculatus), and decorative birds (primarily "Lesser bird-ofparadise" Paradisaea minor but also the "Twelve-wired bird-of-paradise" Seleucidis melanoleucus). The community had two settlements at the time of our surveys which were relatively close to each other and accessible, and the community still operated as a single unit (we spent most time in Kay 1 ). Access to both settlements was by boat, dependent on river conditions. Clan territories were bounded by river channels.

Metaweja: The mountainous territory reached $900 \mathrm{~m}$ a.s.I. and was steeply incised with an abundance of streams and rivers. Access was challenging with rivers frequently un-navigable by boats due to rocks and low water. People often walked for several days to and from the village. The most valued resources were wild pigs, cassowaries, bird-of-paradise, and sago. Boundaries between clan territories follow rivers and ridges.

Yoke: The territory comprised low-lying coastal mangrove, lakes and tidal swamps (fresh, brackish and salt water) divided by channels with a few low scattered hills. Access by small boat was relatively simple. Important resources included fish, crocodile, sago and coconut (Cocos nucifera).

Access and communication

Local people sometimes walked among settlements but preferred boats when the rivers were navigable. Outboard engines were widely used. Planes could be used to evacuate people needing medical treatment (see later).

There was no phone coverage. Two-way radios provided regular communication among settlements, and were used to plan local flights. Nonetheless, passing boats 
remained a major source of local information. Boats could not easily pass any settlement unobserved - most stopped to exchange news and specific messages were often passed between communities.

\section{Language and education}

Each village possessed distinct local languages (Kay has two). Most people had at least basic Indonesian and many, including most young men, are fluent. Our surveys indicate that most men and women in Yoke had some formal education (156 of 193 selected systematically, with 9 of 193 villagers having higher education i.e. training at college or university) but in less accessible Metaweja (92 of 214 villagers, with 3 of 214 villagers had higher education) and Kay (no systematic data) only about half had any schooling.

\section{External influences}

Government and church missions provide some services. School and clinic buildings exist but staff were generally absent during our work periods. All three villages had elementary schools but only Kay had a secondary school - in the other villages many teenagers (mostly boys) attend secondary school in other towns returning only during school holidays. Government officials visited occasionally, e.g. with health programs and for elections.

Church missions had invested in village buildings and maintained a regional system of light planes and commercial flights to support church activities and evacuate medical emergencies. Kay had a poorly maintained airstrip for small planes.

Construction of an airstrip at Metaweja began in 2011.

Interactions with other outsiders were limited. A team surveyed crocodiles and visited many communities in the 1980s (Frazier 1988). Our own research, and the activities of Conservation International, have involved sporadic visits over a decade. There was no regular tourism (we encountered one independent traveler in 2013). Metaweja villagers recalled a visit by geologists in 1985 (see discussion). 


\section{Livelihoods}

Sago (Metroxylon sagu both wild and planted) was the principal staple in all three communities. Other crops included banana (Musa sp.), coconut (Coco nucifera), cassava (Manihot esculenta), sweet potato (Ipomoea batatas) and taro (Colocasia esculenta). Hunting and fishing provided animal fat and protein. Fishing predominated in the dry season and hunting in wetter months, a cycle that we were told follows animal abundance and fruit seasons. Hunting relies on traditional methods. Though some people own air rifles we saw no evidence of more powerful guns. Fishing involves nylon nets and boats with outboard engines. Gardens, fallows and the areas used for gathering fuel wood tended to be close to habitation, whereas hunting occurred over larger areas.

Aside from the village leader, secretary and some teaching, paid work in the villages was absent. Remittances were important for some families but most households traded products when they needed cash. The villages had kiosks selling basic goods (matches, batteries, thread, detergent, knives, etc.); these were stocked by traders who operated along the main rivers and also bought local products for cash. Trade items included dried fish swim-bladders used in traditional Chinese remedies, dried meat and bird-of-paradise (both skins and live birds). From the 1950s until 2008, when prices fell too low, crocodile skin collection was a lucrative activity for many. Cash crops played a negligible role.

\section{Land ownership, access and controls}

Clear ownership and rights of access and use occurred in all three territories though there are some localized nuances and occasional ambiguities. Some boundary areas were shared between friendly communities, for example Yoke and Subu share fishing rights in Lake Tabaresia. Much depends on local relationships; for example at Metaweja's border with Gunung Surumaja incursions are not tolerated, while Tamaja, another neighboring village, shares the river Hakwa, which marks the border between them. Neighboring villagers are on good terms with Metaweja; they even 
occasionally request and are granted permission to hunt or collect in an agreed area within Metaweja's territory.

Lands within each community territory were further subdivided by clans (marga). Some older sago groves were jointly managed within clans, or occasionally at village level (some sago groves in Yoke) but for recent plantings and all other crops, private ownership applied (individual, family or clan). Most large rivers were accessible to fishing by all villagers regardless of clan, but most other products were subject to clan oversight, rights and restrictions though permission could be requested by others. Rights to land and resources were inherited through the father's clan line though children could sometimes claim certain rights within their mother's clan territory, and we heard of a case (in Yoke) where a family had changed a child's recognized clan to that of the mother.

Informants generally answer questions only about areas under their own clan. (Villagers in Kay were especially reluctant to mention clan territories to outsiders as the village settlement lies within two clan territories, the Tebeiko and the Weriko, and this is recognized as a potential source of conflict among the clans, though clan boundaries are clearly recognized in the surrounding territory).

The communities recognized and enforced various rules governing access and activities in all areas. Details varied by site but access to all areas outside of the main river and the village required pre-existing rights or specific permission. Some areas were strictly protected and all extractive activity prohibited: these included sacred areas such as mountains in Metaweja, lakes and springs in Kay, and certain channels among the mangrove in Yoke (the latter covering an estimated $5 \%$ of the territory). Community members seldom entered such areas due to concerns about harmful spirits. Entering them "safely" required formal rituals and visitors had to be accompanied by a designated clan member.

Traditional beliefs were influential in preventing hunting and other exploration over extensive sections of territory including sacred areas. People from all three villages would behave differently when passing near or through sacred locations: becoming silent, switching off of torches and generally avoiding activities which might draw the 
attention of spirits. Sacred areas were frequently mentioned in Metaweja and Kay. In Yoke the people were uncomfortable with this topic. We believe that this difference reflected the customary leader in Yoke dismissing these old beliefs (he was also a churchman).

\section{Authority roles}

Three sources of authority operate in the villages: traditional, governmental and religious: this tripartite authority is a general feature of the region (Gibson 2007). All formal leaders were men: though many women were highly respected and influential. There was a traditional leader (Ondoafi) in each community along with elders for each clan (kepala marga and kepala suku). In all three communities traditional practices persisted such as in approving marriages. Marriages are not permitted within clans but must take place between them. Generally the woman joins the husband's clan, but in Metaweja we were told that outsiders could marry a local woman as long as they paid, provided a sister to a local man, or agreed to settle in the village.

The government representative was the village leader or kepala desa with a village secretary or sekretaris desa who acted as a deputy. The kepala desa is proposed by the village elders and then has to be endorsed by the head of the Regency who also appoints the secretary. The kepala desa would be expected to report any serious crimes to higher authorities though such interventions were, we heard, very rare. There were no local police or regular police activities in any village. Villagers reported that a sustained fight in a neighboring village (Burmeso) resulted in a kepala desa requesting and being sent a small military contingent who arrested those involved.

All villagers claimed to be Christian. The church was present through pastors (pendeta, guru injii). Christian Missions arrived in 1953 and most villagers formally belong to the protestant church (Gereja Kristen Indonesia) though a few are Seventh Day Adventists. Most people regularly attended church services. The church often encouraged discussions within each village that touched on non-religious matters 
and were often called upon in resolving conflicts. These discussions typically followed the Sunday service directed by the pastor.

In practice most misdemeanors and conflicts were, we were told, addressed by "traditional" means - though the kepala desa and church can be influential. Such roles vary with the leaders and by circumstances; notably Metaweja was unusual in that the customary leader is absent and disengaged (he resided in Kasonaweja) and the government elected leader was also the local pastor and thus held considerable authority.

\section{LITERATURE CITED}

Frazier, S. 1988. Mamberamo River crocodile monitoring patrol in the Pagai area. FAO, Jaya Pura.

Gibson, T. 2007. Islamic narrative and authority in Southeast Asia. Palgrave Macmillan, New York, USA. 